\title{
Os canhões de lpanema: tecnologia, indústria, logística e política em 1840
}

Cannons from Ipanema: technology, industry, logistics, and politics in 1840

hitps://doi.org/10.1590/1982-02672021v29e57

\section{FERNANDO JOSE GOMES LANDGRAF'}

hitps: / / orcid. org/0000-000 1-5390-0879

Universidade de São Paulo / São Paulo, SP, Brasil

\section{ADLER HOMERO FONSECA DE CASTRO²}

https:// orcid.org/0000-000 1-6389-3529

Instituto do Patrimônio Histórico e Artístico Nacional / Rio de Janeiro, RJ, Brasil

\section{PAULO EDUARDO MARTINS ARAUJO ${ }^{3}$}

https://orcid.org/0000-0003-3161-7604

Universidade Estadual de Campinas / Campinas, SP, Brasil

\section{LUCIANO BONATTI REGALADO ${ }^{4}$}

https://orcid.org/0000-0002-0521-7618

Instituto Chico Mendes de Conservação da Biodiversidade / Iperó, SP, Brasil

\begin{abstract}
1. Graduado em engenharia metalúrgica pelo Centro Universitário da Fundação Educacional Inaciana (FEI). Mestre, doutor e livre-docente em engenharia metalúrgica pela Escola Politécnica da Universidade de São Paulo (Poli-USP). É professor titular da Poli-USP. E-mail:<f.landgraf@usp.br>.
\end{abstract}

2. Graduado em história pela Universidade do Estado do Rio de Janeiro (Ueri), mestre em história pela Universidade Federal Fluminense (UFF) e doutor em história pela Universidade Federal do Rio de Janeiro (UFRJ). Atualmente é pesquisador da Fundação Cultural Exército Brasileiro, pesquisador associado ao Centro de Pesquisa em História do Exército, sócio do Instituto de Geografia e História Militar do Brasil e assistente técnico em pesquisa do Instituto de Patrimônio Histórico e Artístico Nacional (Iphan), onde também atua como professor do mestrado profissional. E-mail: <ahfc@ centroin.com.br>.

3. Graduado em história com complementação em antropologia e sociologia pela Faculdade de Filosofia, 
Letras e Ciências Humanas da Universidade de São Paulo (FFLCH-USP), mestre em ciências sociais aplicadas à educação pela Universidade Federal de Minas Gerais (UFMG). E-mail: <araujo.pem@gmail.com>.

4. Graduado em ciências biológicas pela Pontifícia Universidade Católica de São Paulo (PUC-SP), com os títulos de mestre e doutor em ciências da engenharia ambiental pela Universidade de São Paulo (USP). Exerce atualmente a função de analista ambiental no Instituto Chico Mendes de Conservação da Biodiversidade (ICMBio). E-mail:<luciano.regalado@ icmbio.gov.br>.
RESUMO: Este trabalho apresenta informações de documentos inéditos de 1840, com as descrições da fabricação de três canhões, um fato técnico a ser rememorado, pelo ineditismo, pelos desafios técnicos que superou e pelos registros descritivos na Fábrica de Ferro de Ipanema, realizados pelo major João Bloem, o então diretor, e das agruras resultantes da Revolta Liberal. Nesse momento, a expansão da indústria paulista do açúcar coincide com a aplicação de recursos na Fábrica durante a regência Feijó, para suprir a demanda por máquinas e componentes em ferro fundido utilizados na moagem da cana por centenas de engenhos paulistas e mineiros. Não se faziam canhões de ferro no país e as armas foram fundidas, usinadas e submetidas a testes de resistência a disparos com cargas de pólvora. Até o final do século XIX, ocorre uma proliferação de fundições de ferro em muitas cidades brasileiras. Como única produtora da matéria-prima das fundições - o ferro-gusa - a Fábrica de Ipanema produziu ferro e fundiu os canhões, o que demonstra a presença das competências técnica e metalúrgica, relacionadas aos investimentos no período da Regência e à intenção de retomar o projeto militar original da produção de equipamentos bélicos. Essa soma de conhecimentos e habilidades levou o diretor a defender uma proposta de estabelecer uma filial em Juquiá, perto do porto de lguape, não aceita pelo Ministério da Marinha. Ao apresentar a história desses canhões, este trabalho rememora alguns dos obstáculos que se interpuseram ao sonho de trazer a primeira Revolução Industrial ao Brasil.

PALAVRAS-CHAVE: Fábrica de Ferro de Ipanema. Fundições. Canhão. Ferro fundido. João Bloem.

ABSTRACT: Unpublished documents from 1840 describe the fabrication of three cannons - a technical fact to be remembered due to its uniqueness, the technical challenges and the detailed descriptions provided by major João Bloem, the director of the Fábrica de Ferro de Ipanema, and the difficulties after the 1842 Liberal Revolt. The expansion of the sugar industry in São Paulo is concurrent with the investments in cast iron machines and components used to grind sugarcane for hundreds of sugar mills from Sorocaba to the South of Minas Gerais, made during Feijo Regency. The iron cannons were the only ones made in Brazil; they were cast, milled, and submitted to firing tests with gunpowder charges three times higher than the regularly used. Although iron foundries spread to many Brazilian cities, they all used imported cast iron, for until the end of the 19th century lpanema was the only place where the raw material, cast iron, was produced from iron ore. The casting of cannons demonstrates the presence of sophisticated metallurgical and technical competence, related to the investments of the Regency period and the intention to regain the original objective of producing military supplies in that plant. This experience and the developed competences led the director to propose a subsidiary in Juquiá, near the port of lguape, which was not accepted by the Navy ministry. In presenting the history of these cannons, this paper discusses some of the situations that hindered the dream of bringing the first industrial revolution to Brazil.

KEYWORDS: Fábrica de Ferro de Ipanema. Foundries. Cannon. Cast iron. João Bloem. 
Seria fastidioso para o leitor narrar tudo o que vimos, contar, por exemplo, que aquele monstrengo de aço fora um canhão dos nossos valentes colonizadores lusitanos. Correio Paulistano. ${ }^{5}$

○ jornalista que acompanhou Sérgio Buarque de Holanda na visita ao Museu Paulista, em 1947, não gostou da história daquele canhão. Aqui, a ideia é restituir história a outro dos canhões daquele acervo. Ele foi e continua sendo símbolo e pretexto. Símbolo de domínio tecnológico e pretexto para convencer os leitores a embarcar em uma outra aventura. Em 1840, a aventura era a de investir em uma escala muito maior. Em 2020, é a de reinserir lpanema na história do Brasil.

A tecnologia aparece, dentro do conceito discutido por Rui Gama: ${ }^{6}$ a soma de ciência e técnica, em que esta precede aquela. João Bloem, diretor da Fábrica de Ferro de São João de lpanema, fabricou canhões e moendas, lia os melhores livros da época e escreveu sobre isso - não em revistas científicas, mas em cartas e mais cartas para o Ministério da Guerra. Com certeza não era o único capaz de fazê-lo, pois cinco anos depois Mauá criava uma fundição com mil empregados. Graças às suas cartas é possível contemplar um empreendedor (com as ilusões típicas dos empreendedores) ${ }^{7}$ que demonstra uma competência técnica surpreendente para a imagem construída sobre o Brasil em meados do século XIX, buscando enfrentar os desafios que o fornecimento regular de carvão e a distribuição dos produtos da fábrica the traziam, e isso tudo imerso num debate político que até hoje continua a dividir os brasileiros.

Os anos entre 1801 e 1900 poderiam ser chamados de "Século do Ferro". $\bigcirc$ consumo desse material aumentou mais de quarenta vezes: passou de menos de um milhão de toneladas anuais ${ }^{8}$ para 40 milhões, no mundo. ${ }^{9}$ A indústria, as ferrovias e a navegação a vapor causaram uma revolução nos transportes de pessoas e de mercadorias. As cidades se transformaram com a iluminação a gás, a água encanada e o esgoto viabilizados por tubos de ferro. $\bigcirc$ Crystal Palace da Exposição Universal de Londres e a biblioteca Sainte Geneviève, em Paris, ambas estruturas metálicas em ferro fundido inauguradas em 1851, colocam em evidência a arquitetura e os sistemas construtivos dessa época.

mobiliário urbano se sofistica e esculturas de ferro fundido, postes, quiosques e bancos, vendidos por catálogos, irradiam-se por quase todas as cidades do planeta. ${ }^{10}$ Gradis de ferro batido perdem espaço para o ferro fundido. A cozinha se transforma, popularizando o uso de talheres de ferro forjado, panelas e fogões de ferro fundido. Até na indumentária o ferro chega, com as joias conhecidas como fer de Berlin. " Em Minas Gerais, pequenas forjas produziam ferramentas agrícolas, as alavancas e cavadeiras de ferro necessárias na mineração. Em várias regiões do Brasil, difundem-se as serralherias e as fundições
5. Nestas paragens... (1947).

6. Gama (1985).

7. Cf. Lovallo e Kahnemann (2005).

8. Esse valor é uma estimativa dos autores com base em interpolação de dados de vários autores.

9. Cf. The New International Encyclopaedia (1905).

10. Cf. Kühl (1998), Junqueira (2005) e Lima (2008).

11. Cf. Santos (2021) e Landgraf (2020). 
12. Cf. Barros (2015).

13. Ferro coado era o nome dado naquela época ao ferro-gusa, a liga de ferro e $4 \%$ de carbono usada em fundição. Os fornos de então eram incapazes de chegar a $1.600{ }^{\circ} \mathrm{C}$, temperatura necessária para fundir ferro puro. Com $4 \%$ de carbono o ponto de fusão baixa para $1.200{ }^{\circ} \mathrm{C}$, temperatura bem mais fácil de ser atingida. Usar ferro velho coado corresponde a usar sucata de ferro-gusa na fundição de novas peças

14. Jaques (1837).

15. O fotógrafo Marc Ferrez é sobrinho de seu homônimo e filho de Zepherin Ferrez.

16. Irineu Evangelista de Souza (1813-1889) foi um comerciante, industrial e banqueiro brasileiro, visto como o maior empreendedor do Império.

17. Souza (1879). de ferro, fabricando objetos baseados em matérias-primas e modelos importados. O consumo de ferro brasileiro passa de 3 mil para 63 mil toneladas anuais ao final do século, quando a metade se referia à importação de trilhos. ${ }^{12}$

A virtual ausência de produção de matéria-prima não impedia uma certa prosperidade do negócio do ferro, usando ferro-gusa e carvão coque importados ou a sucata já disponível no Brasil. Em 1837, em um artigo para o primeiro número do jornal $\bigcirc$ Auxiliador da Indústria Nacional, o cônsul francês no Brasil reportou:

A capital possui três estabelecimentos importantes de fundição de ferro e de cobre, que são a dos senhores Ferrez, membros desta sociedade, Paris \& Parot e Fleury. $\bigcirc$ primeiro arriscou-se antes de outro qualquer, a fundir peças novas com ferro-velho coado ${ }^{13}$ e já tem feito grandes serviços ao Brasil pela variedade de obras e mecanismos que tem saído daquela oficina, cujos foles e fornos são movidos por água. A segunda, situada no centro da cidade, trata das mesmas obras que a primeira e tem de mais a combinação de obras de madeira. A terceira é bem conhecida pela perfeição das bombas que fabrica, assim como todas as peças hidráulicas de metal. ${ }^{14}$

Os proprietários da primeira fundição são os mais conhecidos, Marc Ferrez ${ }^{15}$ e Zepherin Ferrez, por trabalharem com fundição artística. Em 1844, a primeira edição do Almanak Laemmert cita a existência de oito fundições, incluindo as de Fleury e de Paris \& Parot, mas sem citar a de Ferrez nem a fundição de Ponta da Areia, do inglês Colemann, que seria comprada por Mauá, dois anos depois. Em 1866, já eram dezenove fundições no Almanak.

Foi em 1840 que o Barão de Mauál' 16 fez a primeira viagem à Inglaterra, onde, ao visitar uma fundição em Bristol, imaginou um novo caminho para seus negócios:

Era já então, como é hoje ainda, minha opinião que o Brasil precisava de alguma indústria dessas que podem medrar sem grandes auxílios, para que o mecanismo da vida econômica possa funcionar com vantagem; e a indústria que manipula o ferro, sendo a mãe das outras, me parecia o alicerce dessa aspiração. ${ }^{17}$

A navegação a vapor já estava por aqui. Em 1835, foi estabelecido o transporte regular a vapor de passageiros entre o Rio de Janeiro e Niterói. No ano seguinte, criou-se a Companhia Brasileira de Paquetes a Vapor para fazer a ligação marítima da Corte com as cidades da região Norte até o Pará. Entretanto, nem tudo andava tão depressa. A Inglaterra já tinha 2.500 quilômetros de ferrovias, em 1840, os Estados Unidos operavam 3 mil quilômetros e esse número aumentaria 
quatro vezes em 10 anos, nos dois países. $\bigcirc$ regente Feijó garantiu privilégios a quem implantasse ferrovias, em 1835, mas os primeiros quinze quilômetros só foram inaugurados por Mauá em 1854.

Mesmo com o crescimento da demanda por ferro e ainda que fosse conhecida a existência de jazidas de minério de ferro no país, apenas uma siderúrgica funcionou no Brasil, ao longo do século, produzindo ferro fundido e ferro batido, as matérias-primas da indústria: a Fábrica de Ferro de Ipanema, em Sorocaba. Coexistiu com uma centena de pequenas "forjas", em Minas Gerais, cuja produção total de ferro batido não chegava a mil toneladas anuais, ${ }^{18} \mathrm{em}$ 1885. Só em 1890, uma segunda siderúrgica, privada, entra em funcionamento regular: a Usina Esperança, em Itabirito, Minas Gerais, produzindo ferro fundido. ${ }^{19}$

Ipanema foi o maior investimento siderúrgico brasileiro no século XIX e, a despeito das muitas interrupções, produziu milhares de toneladas de ferro. Desde o início, em 1810, os diretores procuraram atender às demandas do mercado: além de lingotes de ferro-gusa para refusão em fundições e barras de ferro batido para uso em ferrarias e serralherias, Ipanema produzia o que chamavam de ferro modelado, em produtos como chapas de fogão las chapas com três bocas, usadas em fogões à lenha), panelas e peças para as moendas de cana, ${ }^{20}$ além de caixas de rapé, castiçais e bustos de artistas. ${ }^{21} \bigcirc$ acervo presente hoje na Floresta Nacional de lpanema mostra vasos ornamentais, escadas em espiral e grades de janelas.

Por volta de 1840, a Fábrica, na prática, era uma fundição de produtos acabados. $\bigcirc$ balanço de sete anos de operação, entre 1834 e 1841, totaliza a produção em 100 toneladas de ferro batido em barras e 904 toneladas de "ferro modelado". Cita mais de 50 produtos diferentes, incluindo 139 balaústres, 2.197 caçarolas, 326 chapas de fogão, 647 cilindros para engenhos de açúcar, 15 ferros de engomar e 5 varandas. Esse balanço ${ }^{22}$ lista para quem foram vendidos cilindros para engenhos de açúcar. Com base nele, é possível listar o número de clientes de cada localidade, na província de São Paulo: Vila de ltu (3 1), Capivari (23), Porto Feliz (18), Campinas (17), Constituição/Piracicaba (12), Limeira (3), Sorocaba (5), Mogi Mirim (4), São Paulo (3), Jundiaí (2), Pirapora (3), Santos (3). A Fábrica atendeu também clientes da província de Minas Gerais, em Jacuí, Pouso Alegre, Caldas, Soledade, São Gonçalo e Lavras do Funil, e do Mato Grosso (Cuiabá), além de mandar material para os arsenais no Rio de Janeiro. A Figura 1 mostra a área do mapa da província de São Paulo editado em 1848, destacando algumas das localidades acima citadas e os caminhos que existiam entre elas.
18. Cf. Ferrand (1885).

19. Cf. Araújo et al. (2017).

20. Cf. Eschwege (1833).

21. Cf. Varnhagen (1857).

22. Cf. Bloem (1841). 


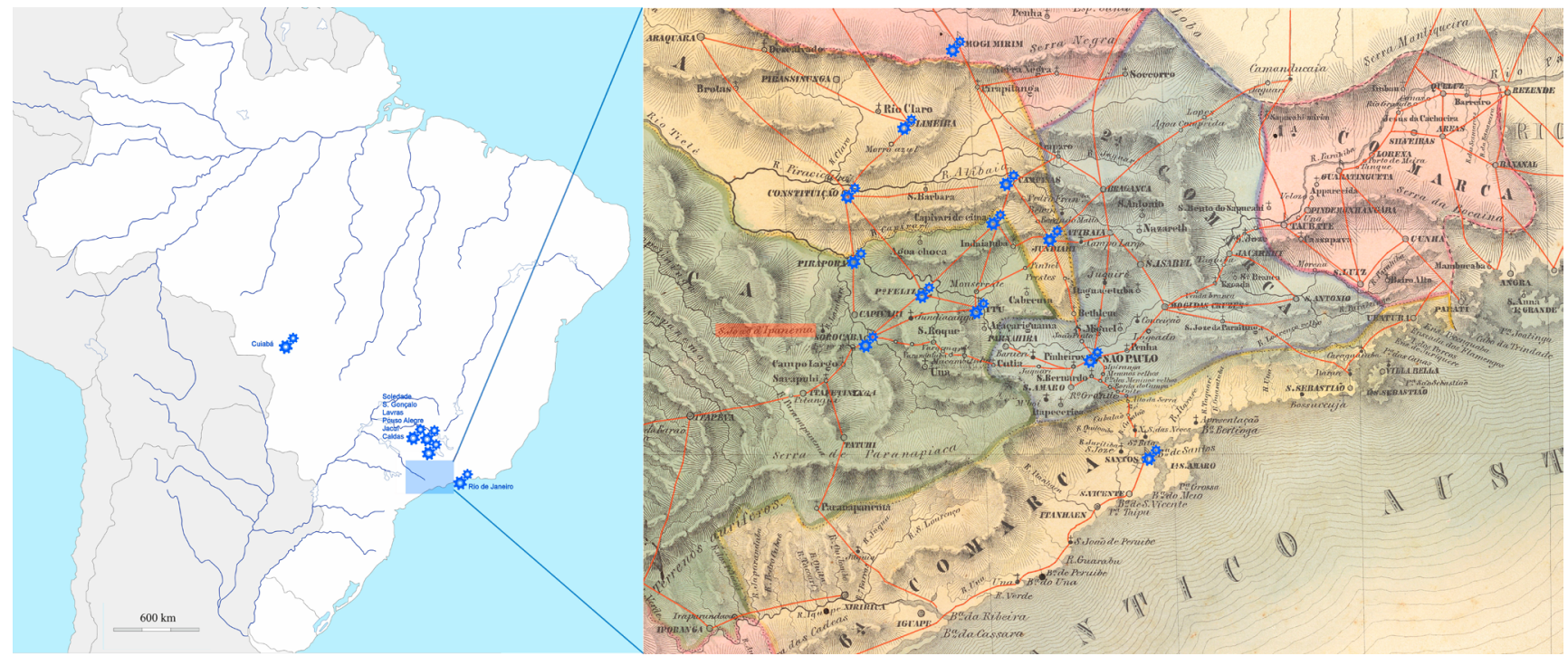

Figura 1 - Localidades que receberam produtos da Fábrica de Ferro de Ipanema entre 1834 e 1841, com as vias de ligação existentes em 1847. Adaptação do Mapa da Província de São Paulo (Didot, 1847).

23. Id., 1840a.

24. Id., $1840 \mathrm{~b}$.

25. Cf. Eschwege (1833), Calógeras (1895), Felicissimo (1969) e Telles (1983).

26. Cf. Santos (2009), Tomasevicius (2012), Faciaben (2015), Ribeiro (2016), Danieli (2006).
Um conjunto importante de objetos foram os três canhões ofertados para o ministério da Guerra, ${ }^{23}$ um dos quais se encontra hoje no Museu Paulista; os outros dois estão em Sorocaba (Figura 2). Devem ter sido as maiores peças ali fundidas e podem ter exigido a operação simultânea dos dois fornos para gerar a quantidade de ferro líquido, necessário às fusões. Cada canhão pesa cerca de setecentos quilos, mas seria necessário incluir o peso dos canais de alimentação e o peso da massa adicional que alimenta o molde durante a solidificação. Os canhões foram fundidos para demonstrar, aos Ministérios da Guerra e da Marinha, a competência técnica da Fábrica. ${ }^{24}$

A Fábrica nasceu como uma sociedade por ações, mas esteve sob a direção do Ministério da Guerra durante a maior parte dos 115 anos de vida. Em três ocasiões, em 1810, 1838 e 1872, o governo fez grandes compras de equipamentos e contratação de equipes de mestres e operários estrangeiros, sempre com a expectativa de que viria a ser autossuficiente. A história de lpanema já foi objeto de muitos trabalhos, ${ }^{25}$ mas a gestão de João Bloem, major do Exército Brasileiro, entre 1835 e 1842, merece maior aprofundamento. Quatro dissertações do departamento de História da Universidade de São Paulo e uma da Unicamp incluem o período Bloem na abordagem, ${ }^{26}$ mas não tratam da fundição dos canhões.

Este trabalho é baseado no exame de material disponível no Arquivo Nacional, no Rio de Janeiro, em pastas relativas ao Ministério da Guerra, que revelam as circunstâncias que levaram aquela Fábrica a fundir, usinar e testar três canhões, em 1840, os únicos canhões de ferro fundidos no Brasil, como parte 
de uma estratégia de convencimento do ministério sobre a conveniência de ampliar a Fábrica, estabelecendo uma filial para fabricar barcos a vapor, no porto de Juquiá27 (Figuras 1 e 5).

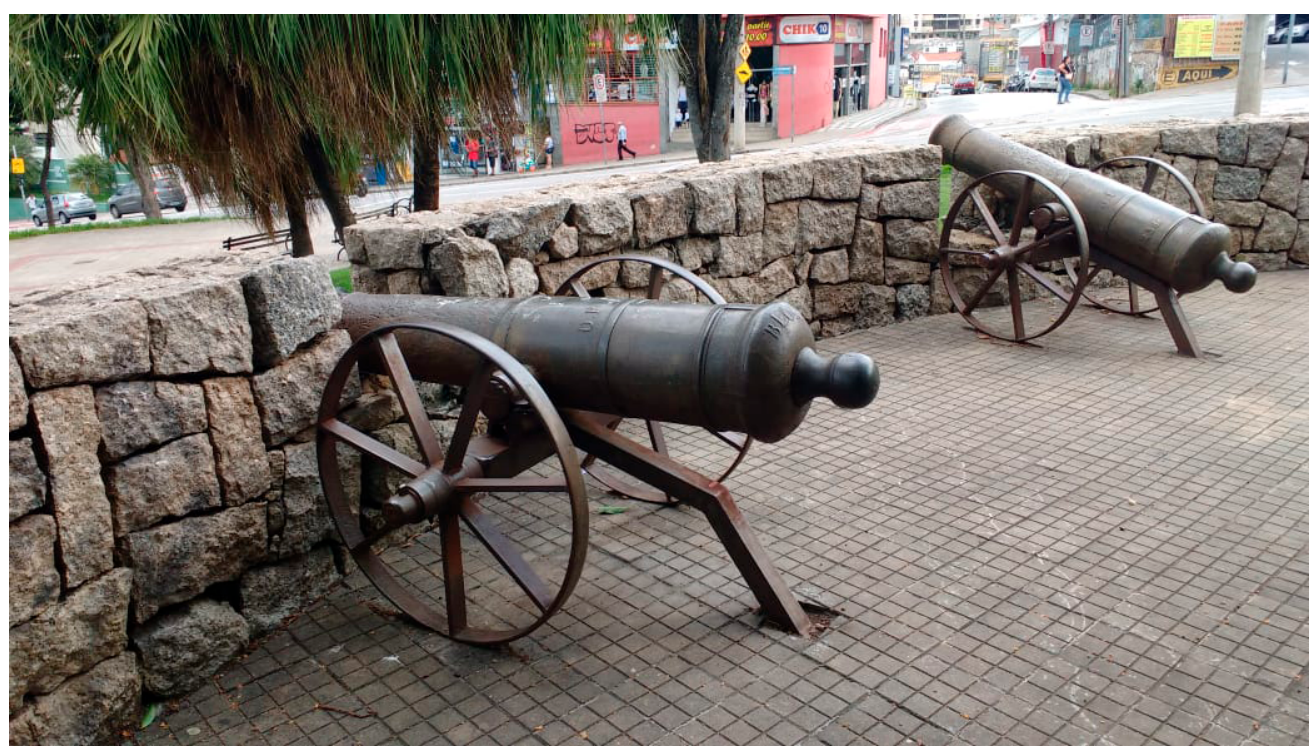

Figura 2 - Dois dos canhões fabricados por João Bloem, em praça pública, Sorocaba. As rodas e o suporte são de adaptação posterior, no século XX. Fonte: Coleção Adolfo Frioli.

João Bloem, ${ }^{28}$ depois de trabalhar como militar de engenharia para $\circ$ governo de Pernambuco, entre 1829 e 1834, foi designado para participar da direção de lpanema em 1834. Ainda não se sabe em que circunstâncias Bloem adquiriu conhecimentos sobre siderurgia, mas em junho de 1835, ele solicitou uma respeitável lista de livros sobre metalurgia e mecânica, e o envio de dois "calorômetros", que são os medidores de temperatura da época. Seu desempenho na Fábrica, nos dois primeiros anos, recebeu menções elogiosas de dois presidentes da província, Tobias de Aguiar ${ }^{29}$ e Gavião Peixoto. ${ }^{30}$

João Bloem escreveu, em junho de 1836, uma carta contendo uma proposta ao Ministro da Guerra, ${ }^{31}$ considerando ser impossível contar com os escravizados para melhorar os processos da Fábrica, ${ }^{32}$ que the fosse facultado viajar para a Europa, para regiões em que "o minério e o combustível tenham a mais completa analogia com os deste estabelecimento", para lá contratar 33 pessoas, 13 mestres experientes em altos fornos, refino, fundição e serralheria, e 20 aprendizes; além de adquirir obras tecnológicas, instrumentos e máquinas (um torno, um laminador, uma máquina de cortar pregos, um fole de 3 cilindros para soprar 2.400 pés cúbicos de ar por minuto). A proposta foi bem recebida pelo Regente Feijó, mas a partida foi atrasada pela dificuldade em encontrar um substituto que assumisse as tarefas
27. Cf. Bloem (1840c)

28. João Bloem. Entrou no serviço militar brasileiro em 1823. Diretor da FFI entre 1835 e 1842 .

29. Rafael Tobias de Aguiar Político e militar paulista. Foi presidente da província de São Paulo por duas vezes, de 1831 a 1835 e de 1840 a 1841 .

30. Bernardo Gavião Peixoto. Foi um militar e político brasileiro. Foi presidente da província de São Paulo entre 1836 e 1838 e entre 1847 e 1848.

31. Bloem (1836).

32. Vários trabalhos abordaram o papel dos escravizados em Ipanema: Cf. Rodrigues (1997), Danieli (2006), Ribeiro (2017) e Oliveira (2020). 
33. Cf. Oliveira (1837).

34. Cf. Bloem (1838).

35. Elberfeld é hoje um distrito da cidade de Wuppertal. Em meados do século XIX, Elberfeld e a vizinha Barmen eram as cidades mais industrializadas da Alemanha. Ali Bloem comprou várias máquinas.

36. Cf. Simões et al. (2003).

37. Cf. Bloem (1840f). que Bloem deixava. ${ }^{33}$ Viajou no segundo semestre de 1837 e ao chegar à Inglaterra foi surpreendido pela resistência do banqueiro inglês, que deveria lhe disponibilizar o crédito de 8 mil libras (correspondente a 65 contos de réis), ao saber, em novembro de 1837, que um novo ministério havia sido formado em substituição a Feijó. Entretanto, graças ao apoio do embaixador brasileiro, o crédito foi liberado e Bloem pôde dirigir-se à Bélgica e depois à Alemanha, para cumprir sua missão. Uma das poucas cartas disponíveis do período de viagem, ${ }^{34}$ enviada de Elberfeld, revela que Bloem continuava com os pensamentos no Brasil. Ele pede que se ordene ao seu substituto que prepare as obras para receber a equipe que trará, que prepare matéria-prima para a retomada de operação da Fábrica. Arrisca dizer:

muito fraternalmente reclamo a V. Excia. no caso de não terem ido os 160 africanos que segundo disse o ex-ministro estão empregados nas Obras Públicas da província do Rio de Janeiro... Julgo que conseguindo-se mais algumas forças e particularmente Matas, muito prosperará a Fábrica do lpanema, e teremos então estabelecida para o fornecimento de objetos bélicos para os Arsenais da Guerra, como para o incremento da Indústria Nacional, com muita influência sobre a Cultura do Brasil. [...] Não tenho deixado de procurar fornecer muitos modelos de tudo aquilo que com proveito se poderá manufaturar no lpanema, com aplicação para facilitar os agricultores de açúcar, café, algodão e, particularmente, à condução por carros próprios e adequados ao País. ${ }^{35}$

Sua viagem, ainda que não se caracterizasse como uma viagem de aquisição de conhecimento, ${ }^{36}$ mas como uma viagem de compras técnicas, com certeza trouxe conhecimento e ampliou sua visão do negócio do ferro. Voltou ao Brasil em outubro de 1838, trazendo para lpanema 43 empregados europeus, 13 parentes destes, e mais equipamentos do que originalmente solicitara, além de outras duzentas pessoas para trabalhar na construção de uma nova transposição da Serra do Mar, entre Santos e São Paulo, contratadas a pedido do presidente da província de São Paulo. Entretanto, seu substituto pouco lhe preparou; as obras de manutenção das casas e dos edifícios não foram feitas, as matérias primas não foram preparadas. Como os africanos não foram enviados, e as matas continuavam em falta, buscou o apoio do Ministério da Guerra, ao qual a Fábrica respondia, embora a política tivesse mudado. A única providência conseguida foi o envio de quarenta africanos, em 1840, muitos deles doentes ou inválidos. ${ }^{37}$

Neste trabalho, valores monetários serão apresentados várias vezes, em contos de réis. Para contextualizar o valor de 65 contos de réis, o balanço de ano contábil 1839-1840 indicou receitas de 33 contos, sendo que as vendas de produtos alcançaram 22 contos, e as despesas anuais foram de 34 contos, incluindo 14 contos de salários. $O$ salário do diretor maquinista, o inglês Godwin, era de 1,6 contos por 
ano ${ }^{38}$ e o soldo anual de um major com comando de unidade era de um conto de réis. Bloem estimou que com 80 contos ele compraria cento e oitenta escravos.

A distância do porto de Santos (na época, 32 léguas ou $210 \mathrm{~km}$ ) dificultava a entrega dos produtos fundidos para regiões mais distantes, carregados no lombo de burros, pois a maior parte dos caminhos não era carroçável. ${ }^{39} \mathrm{~A}$ necessidade de uma alternativa, que seria uma conexão entre Sorocaba e o porto de lguape, vinha sendo apresentada com insistência pelos políticos locais. ${ }^{40} \mathrm{Com}$ base nisso, Bloem propõe, em cartas ao ministro da Guerra, criar uma outra instalação industrial num porto próximo de Ipanema. Assim, a Fábrica de Ipanema seria a produtora da matéria-prima, o ferro-gusa, que seria transportado em pedaços pequenos para serem refundidos nessa nova instalação, produzindo peças maiores, transportadas por barcos para o Rio de Janeiro e outras cidades portuárias do Brasil. Ele chegou a identificar um possível porto, no rio Juquiá, no vale do Ribeira de lguape. Foram várias cartas defendendo essa tese, afirmando que nada faltava para instalar um estabelecimento no Juquiá: rio navegável, combustível em abundância, clima sadio, víveres em grande quantidade e fácil de defender de forças externas.

Em 1840, surgiu uma oportunidade. A Marinha do Brasil divulgou em fevereiro um aviso de que pretendia estabelecer uma oficina de construção de máquinas para barcas de vapor no Arsenal de Marinha, no Rio de Janeiro. Bloem escreveu uma carta ao ministro da Marinha, em 27 de abril de 1840, propondo que fosse criada uma oficina de construção de barcas de vapor e fundição de objetos bélicos, e o melhor lugar seria num porto no rio Juquiá, na província de São Paulo. ${ }^{41}$

Nesse documento, publicado na edição de 19 de maio de 1840 do jornal Correio Oficial, na seção Ministério da Marinha, ${ }^{42}$ ele argumenta que o Rio de Janeiro não seria um bom local para um empreendimento desse tipo: os salários a serem pagos seriam altos e o custo de vida elevado; a evasão dos estrangeiros seria grande, pois faltavam os divertimentos dominicais que havia nos países de origem; faltava moralidade; faltaria a energia hidráulica necessária para tocar as máquinas e não haveria boa madeira para a construção dos barcos. $\bigcirc$ tema da retenção dos estrangeiros deve refletir a visão de Bloem sobre as dificuldades que teve com os 43 operários que trouxe da Alemanha para lpanema dois anos antes, dos quais só 19 permaneceram.

João Bloem argumentou ter experiência para conceber um projeto daquela escala, pois havia visitado mais de sessenta empresas metalúrgicas na viagem à Europa, já estava fornecendo rodas dentadas, engrenagens, cilindros, moendas de ferro e máquinas a vapor para os engenhos de açúcar do interior de São Paulo e sul de Minas, fundindo e usinando cilindros de até 1,2 metros de diâmetro. Bloem encerra o texto da proposta com uma frase lapidar: "assim,
38. Id. 1839.

39. Cf. Scully (1866).

40. Cf. Almeida (1950)

41. Cf. Bloem (1840b).

42. Id., 1840c. 
43. Ibid.

44. Cf. Coimbra (1974).

45. Cf. Bloem (1840d).

46. Modelo é o nome que se dá, na prática metalúrgica, a um objeto de madeira ou de metal que tem a forma do objeto que se deseja fundir, mas cujas dimensões são calculadamente maiores. Esse modelo é usado para fazer a cavidade do molde de areia, em que será vertido o metal líquido. Ao solidificar, o metal se contrai e chega às dimensões desejadas.

47. Calibre 6 é o peso do projétil, 6 libras, ou seja, $2,9 \mathrm{~kg}$.

48. Broquear é fazer um furo com uma broca. Bloem pretendia usar um único modelo, fundir peças e broquear furos de diâmetros diferentes.

49. General Thomas Blomefield (1744-1822).

50. Arsenal de Woolwich foi um dos mais importantes estaleiros da marinha inglesa nos séculos XVIII e XIX, comportando também a Royal Military Academy.

51. Bloem (1840d). pouco a pouco, se vai aumentando a Indústria Nacional, chegando ao mesmo prazer que tem elevado os corações dos cidadãos dos Estados Unidos. Foi só o amor à indústria que fez aquele povo tão feliz" ${ }^{43}$

Bloem apresentou, em anexo àquela carta, um detalhado orçamento do custo de implantação da oficina, chegando a 430 contos de réis, a serem investidos em quatro anos, e que então começariam a trazer resultado econômico. Esse valor parece razoável, quando comparado aos 360 contos que Irineu Evangelista de Souza, o Barão de Mauá, investiu na aquisição e ampliação da fundição e estaleiro de Ponta da Areia, em Niterói, entre 1846 e 1848. No entanto, a instalação de uma ferrovia entre Ipanema e o futuro porto de Juquiá teria um custo muito maior. É importante lembrar que, naquele momento, não havia nenhuma ferrovia em operação no Brasil. A primeira seria inaugurada por Mauá, em 1854. Os quinze quilômetros dessa ferrovia do Rio de Janeiro a Petrópolis custaram 1.500 contos de réis. ${ }^{44}$

Aquela carta com a proposta não teve resposta imediata. $\bigcirc$ momento político era complexo. A Regência estava em crise terminal. $\bigcirc$ grupo político que apoiara o investimento de modernização de lpanema, liderado por Diogo Feijó entre 1835 e 1837, com o apoio de Tobias de Aguiar e proprietários de engenhos de açúcar do interior paulista, fora alijado do poder, substituído por um grupo contrário aos investimentos.

Naquele mesmo dia 27 de abril de 1840, Bloem escreveu uma outra carta para o Ministério da Guerra, ${ }^{45}$ informando que enviara a proposta acima ao Ministério da Marinha, e que tinha um plano para fundir canhões:

Eu mandei fazer, há tempos, um modelo46 de uma peça de calibre 6 pela forma ordinária para uso da Armada. ${ }^{47}$ Vou experimentar a broquear ${ }^{48}$ no mesmo modelo e quero adaptar para calibre 9, pois julgo que o nosso ferro é tão bom, que resistirá a toda prova; examinados e experimentados, os farei conduzir para a Corte; julgo que se deva adaptar a artiIharia ao sistema do general Blomefield ${ }^{49}$ que ele inventou quando diretor da fundição de artilharia no arsenal de Woolwich, ${ }^{50}$ pois dão melhor resultado, são mais cômodos no manejo, por que são de menos peso de metal, e curtas, por este motivo preferível por fazer menos peso sobre os lados externos dos navios que, por consequência, não joga tanto..$^{51}$

Padrão Blomefield, adotado na Inglaterra a partir de 1787, continuou em uso generalizado até a década de 1830. Foi o canhão usado na nau capitânia do almirante Nelson, na batalha de Trafalgar, em 1805. Aqui no Brasil, é comum encontrar canhões do tipo Blomefield, pois foram armas adotadas pela Marinha Portuguesa a partir de 1805. Em 1840, esse modelo ainda era 
corrente, mas já considerado antiquado, sendo substituído por peças que seguiam a linha Paixhans (do oficial de artilharia francês Henri-Joseph Paixhans), capazes de disparar balas rasas e granadas, comuns desde o final da década de 1820, pelo menos na Europa. ${ }^{52}$

Na mesma carta, ele descreve como deverão ser fundidos os canhões, dando detalhes técnicos que demonstram a sua experiência nessa técnica. Bloem afirma que o metal líquido deve ser produzido ou nos altos-fornos de lpanema ou em fornos cúpula ou em fornos revérberos. Serei de parecer que sejam fundidos massivos, sem o furo da alma e com a cabeça perdida de 1,5 a 3 palmos de altura, em frascos de ferro próprios para cada calibre, nem em pé nem, tampouco, deitado, sim com uma inclinação de 45 graus, aplicados os gitos pelo lado de baixo, desta maneira as espumas e escória que de ordinário deixam as almas das peças escabrosas, tornam-se compactos e, por consequência, furáveis e sem as desgraças que de ordinário vem dos incêndios de peças quando se carregam, não sendo causado por falta ou negligências no ouvido. ${ }^{53}$

Essa descrição detalhada do processo de fabricação dos canhões é tão técnica que exige uma série de explicações, o que demonstra o conhecimento do diretor e de sua equipe sobre os aspectos técnicos envolvidos. Ao informar que fundirá o metal "em fornos cúpula ou em fornos revérberos", ele se refere aos dois tipos de fornos de refusão do ferro-gusa para obter o ferro líquido a ser vazado no molde. $\bigcirc$ forno de cúpula laté hoje usado e conhecido como forno cubilôl é um forno vertical em que se mistura carvão e o ferro a ser fundido, soprando ar dentro do forno para queimar o carvão e gerar a temperatura suficiente para fundir o metal. Um forno desse tipo, datado de 1900, embeleza o hall de entrada do departamento de engenharia metalúrgica e de materiais da Escola Politécnica da USP. $\bigcirc$ forno revérbero tem disposição horizontal e é aquecido pela reverberação do calor da abóbada do forno, que recebe o fluxo de gás da queima de carvão numa câmara ao lado.

Quando afirma que "serei de parecer que sejam fundidos massivos, sem o furo da alma" indica que o molde não incluirá o furo pelo qual a bala sairá. Ele acha preferível fazer o furo posteriormente, usando a "máquina de broquear", ou seja, o torno mecânico que trouxera da Alemanha. A frase "com a cabeça perdida de 1,5 a 3 palmos de altura, em frascos de ferro próprios para cada calibre" referese ao procedimento comum da fundição, de que é necessário prover um volume de metal líquido adicional ao volume da peça, pois o líquido se contrai ao solidificar e sem essa "cabeça perdida" existe o risco de formar cavidades dentro do canhão, que reduziriam sua resistência. $\bigcirc$ vazio de contração fica localizado nesse volume

52. Cf. Castro e Andrade (1993).

53. Bloem (1840d) 
54. Ibid.

55. Cf. Araujo et al. (2017)

56. Cf. Mamani-Calcina et al. (2016). extra, na cabeça perdida, que ao ser cortada torna a peça sem vazios indesejáveis. De forma secundária, a cabeça serve para comprimir o metal líquido dentro do molde, fazendo com que bolhas de ar subam para a parte da cabeça, na qual não prejudicariam a solidez da fundição. A frase "em frascos de ferro próprios para cada calibre" é estranha, pois como os três calibres seriam usinados a partir do mesmo formato externo, a fundição dos 3 canhões seria idêntica.

$\bigcirc$ trecho em que afirma que o molde não seria posicionado

nem em pé nem, tampouco, deitado, sim com uma inclinação de 45 graus, aplicados os gitos pelo lado de baixo, desta maneira as espumas e escória que de ordinário deixam as almas das peças escabrosas, tornam-se compactos e, por consequência, furáveis e sem as desgraças que de ordinário vem dos incêndios de peças quando se carregam, não sendo causado por falta ou negligências no ouvido. ${ }^{54}$

mostra a atenção do diretor com os detalhes da fundição. Ao posicionar a cavidade do molde com o eixo do canhão a $45^{\circ}$, com o metal entrando no molde por canais (os gitos) que o alimentariam por baixo, Bloem esperava que fosse evitada a turbulência do líquido, que forma, carrega e espuma a escória. Isso permitiria que todo o volume de metal do canhão ficasse compacto, sem defeitos. Quando a furação da alma do canhão fosse realizada, não surgiriam defeitos, pequenas cavidades que poderiam abrigar pólvora no carregamento do canhão e que poderiam gerar acidentes. Por fim, "ouvido" é o canal que liga o exterior do canhão ao fundo da alma, em que fica a pólvora. Pelo ouvido penetra o fogo que dispara o tiro.

É interessante notar que, enquanto Bloem enfatiza o viés da técnica da fundição, vinte anos antes dele, o segundo diretor de Ipanema, Frederico Varnhagen, dava mais atenção à carga do alto forno, ao consumo de carvão e à qualidade do ferro-gusa produzido, em suas detalhadas cartas ao colega metalurgista Eschwege ${ }^{55} \mathrm{Com}$ isso, Bloem nada escreve sobre a regularidade na obtenção de ferro-gusa do tipo cinzento, mais adequado para a fundição, que exige temperaturas mais altas de operação do alto forno. Pode ser que os operadores que Bloem trouxe da Alemanha tivessem um melhor controle do processo. Essas observações geram hipóteses de trabalho para a futura análise da microestrutura das peças fundidas por Bloem, a exemplo do que já foi feito ${ }^{56}$ para objetos de ferro forjado da Fábrica.

Além de explicar os cuidados metalúrgicos da fundição, Bloem tinha mencionado muito simplesmente que iria broquear os três calibres usando o mesmo 
modelo, a mesma forma externa para os três canhões. Broquear o canhão significava cavar um buraco de $10 \mathrm{~cm}$ de diâmetro e um metro e meio de profundidade no interior de uma peça de ferro de mais de $600 \mathrm{~kg}$, sem desviar-se do eixo central. Para isso Bloem trouxe várias máquinas, um diretor para operação das máquinas, G.P. Godwin, de 43 anos, e vários mestres maquinistas, quando voltou da Europa em 1838. João Gutierres, diretor interino da Fábrica em 1849, descreveu a casa das máquinas construída e equipada por Bloem:

é como um complemento da fundição dos fornos altos, sendo ali que se alisam, broqueiam, entalham e ajustam as diversas peças de ferro fundido para moendas de açúcar e outros misteres, cuja venda constitui hoje a principal parte do rendimento desta fábrica. A casa [...] tem [38 metros] de comprimento, [21 metros] de fundo e [6,4 metros] de altura. [...] As janelas do plano térreo da casa são envidraçadas e os caixilhos de ferro.

As máquinas dessa oficina constam de: uma máquina a vapor de alta pressão, força de 6 cavalos, que movimenta todo maquinismo e consome diariamente 2 a 3 carros de lenha; um banco grande de tornear e broquear metais até [1,2 metro] de diâmetro, vindo da Alemanha; outro semelhante feito nesta mesma fábrica; dois ditos menores, um da Alemanha e outro de fábrica inglesa; um outro de aplainar ferro, um torno menor para pequenas obras, vindo da Inglaterra; uma máquina para abrir furos de até [ $5 \mathrm{~cm}$ ] de diâmetro; e finalmente 3 máquinas para fazer parafusos. ${ }^{57}$

Operar essa instalação deve ter exigido muita atenção de Bloem. envidraçamento do prédio foi uma medida importante, pois "o pó impede o bom andamento das [máquinas] e causam estrago pela efetiva friçcão que infalivelmente vem a ter". ${ }^{58} \mathrm{~A}$ lista de objetos comprados incluía os apetrechos associados à operação das máquinas por cinco anos. Seria muito interessante saber mais sobre o material das brocas utilizadas. Provavelmente eram brocas de aço, mas seu desgaste deve ter sido grande. Segundo Percy, só em 1857 surgiram as brocas de aço ao tungstênio, de vida muito maior, fabricadas em Leoben, na Áustria. Infelizmente não foi encontrada a marca do torno, mas sabe-se que veio de Elberfeld, uma cidade da região do Ruhr, bem industrializada naquele momento. Com isso não se tem uma imagem desse torno, essa máquina de broquear, que se adequava tanto a tornear o furo do canhão quanto dos cilindros de máquinas a vapor. A Figura 3 mostra uma imagem quase contemporânea, em um livro inglês de elementos de mecanismos, ${ }^{59}$ de 1852. 
60. Cf. Castro (2017).

61. Cf. Bloem (1840e).

62. Pelo menos duas medidas diferentes de palmo português circularam no século XIX: o palmo português de $22 \mathrm{~cm}$ e o palmo da Junta do Comércio, equivalente a $20 \mathrm{~cm}$. As medidas dos diâmetros das almas dos canhões, de calibre 4, 6 e 9 , são compatíveis com o palmo da Junta do Comércio.

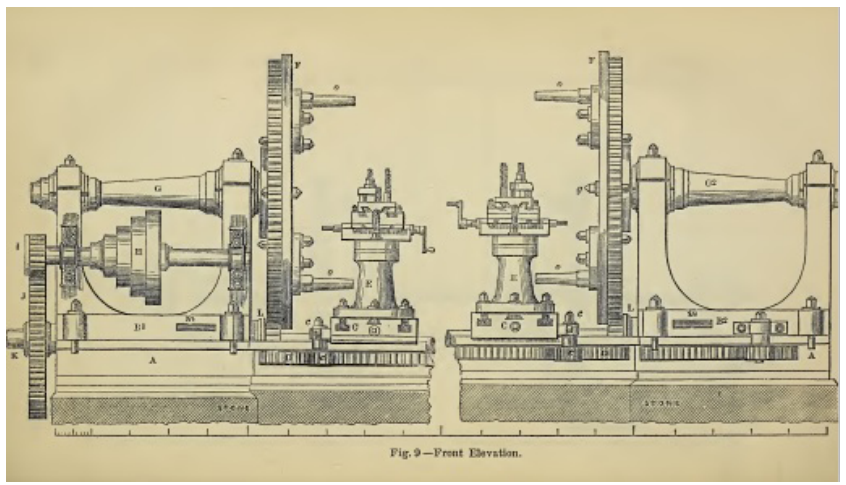

Figura 3 - Desenho de um torno fabricado por Francis Lewis \& Sons, Manchester. Fonte: Baker (1 852).

Tornos para usinar metais já existiam no Brasil, antes dos trazidos por Bloem. Arsenal de Guerra recebeu, em 1829, um torno para perfurar a alma de canhões. $O$ equipamento custou 6 contos de réis e seria instalado em um prédio orçado em 60 contos, que nunca foi construído. ${ }^{60}$ Com isso, a fabricação de canhões pelo Arsenal só viria a acontecer durante a Guerra do Paraguai, em 1865.

Enquanto Bloem apresentava suas ideias ao Ministério da Guerra, a situação política sofreu grande mudança, em julho de 1840. Um movimento dos liberais leva à decretação da Maioridade de Pedro II, a subida de um novo grupo ao poder, conhecido na imprensa da época como "gabinete dos irmãos" pois incluía dois irmãos Andrada, os paulistas Antonio Carlos e Martim Francisco, além de dois irmãos pernambucanos, os Cavalcanti. O ministro da Fazenda que assume é Martim Francisco de Andrada, que conhecia bem a Fábrica de Ipanema, pois participara do projeto conceitual, em 1810, e foi membro do conselho de acionistas até 1813 .

Tudo indica que Bloem percebeu a oportunidade e quis demonstrar, no âmbito dos negócios militares, que lpanema tinha de fato essa competência. Em agosto de 1840, Bloem manda outra correspondência, ${ }^{61}$ perguntando a quem ele deveria enviar, no Rio de Janeiro, os três canhões que tinha fundido, usinado e testado, com carga de pólvora três vezes superior à carga padrão. Bloem incluiu na carta um desenho (figura 4) com as dimensões dos três canhões. Esses três canhões sobrevivem até hoje, têm gravada a data da Maioridade, "23 de julho de 1840", o nome de "Pedro II" e, pelo menos em um deles, o nome do autor, "BLOEM". As dimensões dos três canhões, os dois de Sorocaba e o terceiro que está no acervo do Museu Paulista, são muito próximas das previstas nesse desenho, cujas unidades estão em palmos e polegadas portuguesas: 62 têm cerca de 1,8 metro de comprimento. 


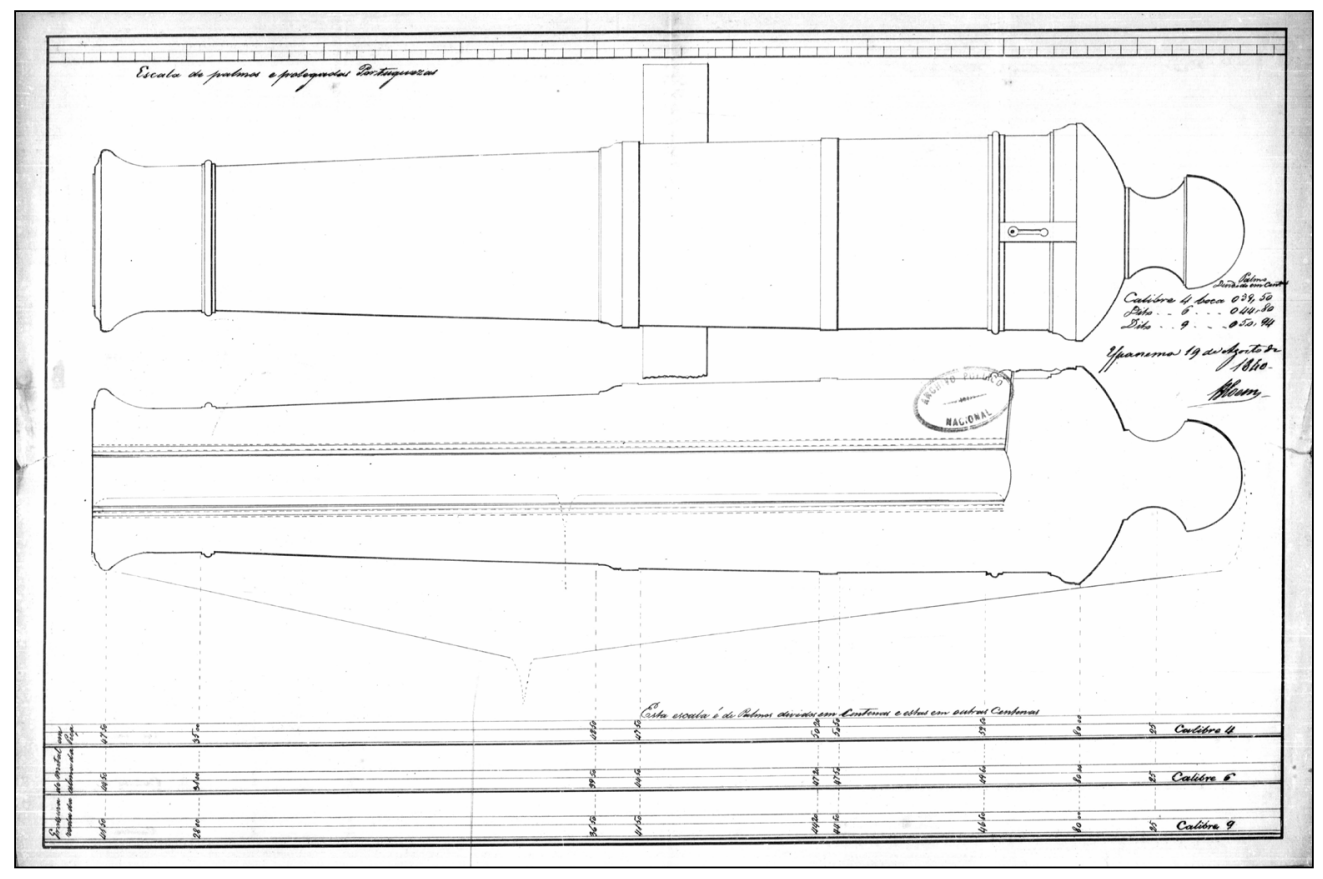

Figura 4 - Desenho do canhão projetado por João Bloem, constante em carta para o Ministério da Guerra. $\bigcirc$ desenho inclui os três diâmetros que foram usados para os três canhões de diferentes calibres. Fonte: Arquivo Nacional.

desenho de Bloem segue os princípios de projeto de um canhão Blomefield, a menos da ausência do anel do vergueiro (um anel de ferro na extremidade oposta à boca do canhão). $\bigcirc$ vergueiro era uma corda, um cabo grosso que prendia o canhão ao costado do navio para que a arma não corresse solta com o balanço do navio ou com o disparo. Entretanto, esse não era um detalhe importante para canhões de terra e, portanto, compreensível que o anel fosse removido em um canhão feito para o Exército. Documentos ingleses falam que a fundição do anel era problemática, pela dificuldade de controlar o fluxo do metal líquido no molde. ${ }^{63}$

$\bigcirc$ calibre dos canhões evidencia várias questões técnicas da época. $\bigcirc$ calibre correspondia ao peso da bala a ser disparada, em libras, o que implica no diâmetro interno, a "alma" do canhão, e no correspondente comprimento ideal para máxima potência de tiro. $\bigcirc$ diâmetro e o comprimento, juntos, estabelecem o peso do canhão e, por consequência, o peso de ferro líquido que deve estar disponível para produzir o canhão. Bloem fabricou canhões de calibre quatro, seis e nove libras, com almas de 7,9,9 e 10,2 centímetros. ${ }^{64}$

Aquela correspondência não mencionou um aspecto que hoje causa estranheza aos historiadores da artilharia: a fundição de três canhões de calibres diferentes e com o mesmo comprimento. Já era bem conhecido pelos fabricantes 
65. Robins (2009).

66. Bloem (1840a).

67. Karsten (1826).

68. Bloem (1835).

69. Capanema (1863). desse tipo de arma que havia uma relação ótima entre o calibre e o comprimento do canhão para garantir máxima energia à bala disparada com carga de pólvora de um terço do peso da bala. ${ }^{65}$ Essa relação ótima foi determinada a partir do ensaio chamado de pêndulo balístico, criado pelo inglês Benjamin Robins, em 1742. Tendo feito muitos experimentos com diferentes relações entre comprimento e diâmetro, Robins concluiu que, quando a relação é da ordem de 17, a bala sai do canhão com a máxima energia.

Analisando as dimensões dos três canhões fabricados por Bloem, apenas os canhões de 4 e 6 libras se aproximam à proporção de comprimento (distância entra a boca e o ouvido) igual a 17 vezes o diâmetro da alma do canhão. Os três canhões fundidos por Bloem têm o mesmo comprimento, uma distância boca-ouvido de 145 centímetros. As proporções dos três canhões são 145/10,2=14,2 para o canhão de 9 libras, relação de 145/9=16 para o canhão de 6 libras; a do canhão de menor calibre, 4 libras, que está na faixa desejada, 145/7,9=18,3.

Não se sabe se Bloem conhecia a relação ideal de Robins, mas ele fez questão de demonstrar que os canhões suportaram carga de pólvora de até 9 libras, maiores do que as utilizadas nos testes, mesmo tendo aberto no interior uma cavidade de diâmetro maior, para caber a bala de calibre 9. E na carta proposta, de abril de 1840, ele justifica: o ferro fundido produzido em Ipanema, por ser fabricado com carvão vegetal, tinha qualidade superior. Isso teria sido atestado pelo "maior metalúrgico da Europa", o conselheiro Karsten. ${ }^{60}$

O prussiano Carl Karsten havia publicado a obra Handbuch der Eisenhüttenkunde [manual de arte siderúrgica] em 1826, reconhecida pelo mundo todo e traduzida para o francês. ${ }^{67}$ Quando Bloem assumiu a direção de lpanema, em 1835, the foi pedida uma lista de livros que deveriam ser comprados para reforçar a biblioteca da fábrica. Bloem respondeu em alguns dias, com uma lista de 24 livros, encabeçada pelo Handbuch e pela revista editada por Karsten. ${ }^{68}$ Outro exemplo do respeito à autoridade de Karsten foi dado pelo engenheiro militar Guilherme Schüch Capanema, quando comentou que o diretor de lpanema que sucedeu Bloem, o tenente coronel Antonio Manoel Mello, achava que tudo se resolveria só por levar o livro do Karsten debaixo do braço. ${ }^{69}$

Bloem, na carta, explica como mediu a resistência dos canhões: "foram fundidas três peças: a primeira com alma para calibre 4, que resistiu com 4 libras de pólvora aos ensaios; a segunda, com alma para calibre 6, resistiu com 6 libras de pólvora aos ensaios; e a última com a alma reforçada em calibre 9, resistiv a ensaios de 9 libras". Nessa época, a carga de pólvora de serviço de um canhão era de um terço do peso do projétil, de forma que o canhão foi testado com uma carga três 
vezes maior do que o normal. Esse era o teste padrão de um canhão. Outros testes - além do exame visual e com ferramentas especializadas - eram o tiro com carga dupla e duas balas, que coloca uma pressão maior ainda na alma do canhão.

Em 5 de setembro de 1840, ocorre uma longa discussão no senado que traduz, com clareza, dois pontos de vista opostos sobre o futuro da Fábrica. ${ }^{70}$ De um lado, o senador Bernardo Pereira de Vasconcelos, contrário ao gabinete liberal, e, de outro, o ministro da Fazenda Martim Francisco e o senador Vergueiro. Selecionando alguns pontos interessantes, o debate inicia-se com Vasconcelos afirmando que:

esta fábrica tem custado e continuará a custar muito dinheiro ao Tesouro; mas o Tesouro não sabe o que a fábrica vende e parece que se esqueceu dos avultados capitais que ali se empregaram; o expediente mais acertado era a alienação da fábrica de lpanema: se esta fábrica se ocupasse ao menos de armamentos, eu, nesse caso, quereria que fosse conservada, ainda que o Tesouro público não tivesse lucro, ainda mesmo que fosse muito prejudicado porque, em matéria de tanta monta, não convém que fiquemos dependentes do estrangeiro, não devemos esperar do fornecimento do comércio as armas necessárias para defesa do País; mas a fábrica de lpanema, como acabamos de ouvir, é fábrica industrial, é um estabelecimento que, pela natureza, deve pertencer a um particular. ${ }^{71}$

Vasconcelos ignorava que a Fábrica fornecia munição para o Exército. Por exemplo, em maio de 1837, o almoxarife de lpanema reportou o envio para o Arsenal de Guerra do Rio de Janeiro de $4.156 \mathrm{~kg}$ de projéteis de artilharia de diferentes tipos, inclusive granadas ocas. ${ }^{72}$ Naquela sessão do Senado, o ministro Martim Francisco respondeu que toda fábrica exige algum tempo para se firmar e dar lucro, que lpanema fabrica e vende todos os tipos de produto de ferro e que, se ainda não dá muito rendimento, é porque the falta carvão, por faltar demarcar área, e o diretor diz que faltam braços. $\bigcirc$ senador Vergueiro veio em apoio:

Esta fábrica não precisaria outro socorro do Estado senão a desapropriação das matas, para não ficar aquele estabelecimento isolado e sem recurso algum de carvão e não se ver na necessidade de ir à grande distância buscar combustível, o que não faria conta; mas, havendo uma certa extensão de matas, está visto que nunca terá falta de carvão, pois que se vão fazendo os cortes anuais com método, e, quando se chega à última mata, as primeiras que serviram estão em termos de produzirem carvão; bom seria que houvesse uma mina de carvão de pedra; conforme o carvão de que se usa e o ferro melhor ou pior, e a razão da diferença que há entre o ferro inglês e o da Suécia é porque um é fundido com carvão de pedra e outro com carvão de madeira; convém estabelecer ali uma escola de indústria tanto de extração como de manufaturação. É para esse fim que deve ser conservada e, por isso, convido o nobre ministro da Guerra a que procure nacionalizá-la, perpetuá-la, metendo ali aprendizes nacionais. ${ }^{73}$
70. Cf. Anais do Senado (1840).

71. Karsten, op. cit

72. Cf. Sagalsova (1837)

73. Karsten, op. cit 
O senador conde de Lages, que fora o ministro da guerra que aprovara o investimento associado à viagem para a Europa, acrescentou que o diretor propôs ao governo um estabelecimento filial para construção de máquinas, no qual se poderiam fazer armas, instrumentos bélicos e mais petrechos militares, até mesmo barcos de vapor. $\bigcirc$ assunto estava, portanto, bem colocado em vários aspectos e tinha o apoio do ministro da Fazenda.

Entretanto, em 22 de setembro de 1840, o ministério da Guerra respondeu que as propostas de Bloem só seriam interessantes se o percurso entre lpanema e o rio Juquiá fosse transitável e se fosse ali construída a oficina de máquinas a vapor, que era um assunto da Marinha. ${ }^{74}$ Ainda não foi localizada alguma resposta da Marinha ao pleito, mas uma análise atual contrasta a geografia com o otimismo de Bloem com relação à estrada: "Este porto fica cerca de 8 a 11 léguas 150 a $70 \mathrm{~km}$ ) do Ipanema, por um terreno bastante plano, que oferece possibilidade da construção de um caminho de ferro desde o lpanema até o porto do rio".

Em linha reta, a distância entre Ipanema e Juquiá é da ordem de 100 quilômetros. Pela atual rodovia SP-79, a distância entre Sorocaba e Juquiá é de 129 km. Sai da cota de 600 metros, em lpanema, tendo que ultrapassar a serra do Paranapiacaba, que ali chega a 1000 metros de altitude, para chegar ao vale do Ribeira de lguape, na cota 20 metros.

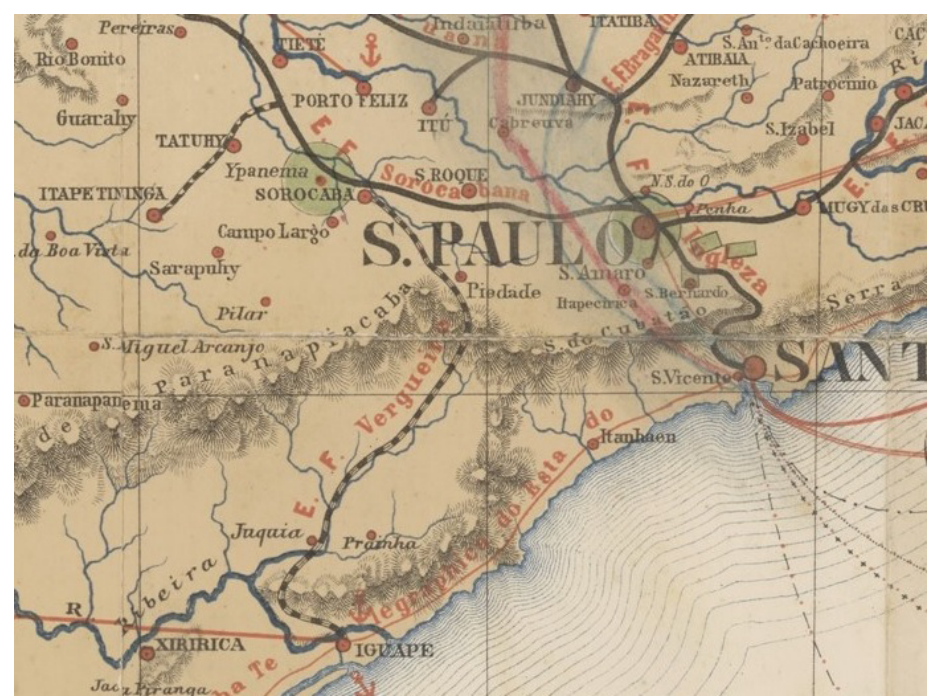

Figura 5 - Trecho de mapa da região sul do estado de São Paulo, mostrando uma estrada de ferro que ligaria Sorocaba a lguape. Fonte: Arquivo Nacional, fundo Decretos do Poder Executivo - Período Republicano. 
A estrada de Sorocaba a Juquiá foi assunto repetitivo na província de São Paulo, durante o século XIX. Martim Francisco escreveu ${ }^{75}$ sobre essa possibilidade em 1805. Gastão Stokler, morador de Juquiá em 1840, comentou que "pouco se usa e se recomenda o caminho do Picadão, que sai de ltapetininga, desce a serra agreste e inóspita com muita dificuldade e pode se chegar ao Juquiá". ${ }^{76}$ Carlos Rath, um engenheiro alemão radicado em São Paulo, investigou a região entre 1845 e 1850 e comentou que "estes sertões são os que têm tornado todos os esforços do governo inúteis para estabelecer vias comerciais de povo a povo. Ainda hoje (1853) não existe uma via que possa servir de comunicação, depois de se ter gasto mais de cem contos de réis". 77 A despeito dos obstáculos, 30 anos depois, outro diretor de lpanema insistiria nesse tema, em vários relatórios anuais da Fábrica: construir uma estrada até o porto do Juquiá. ${ }^{78} \mathrm{Um}$ mapa da província, editado em 1886, previa a existência de uma ferrovia que ligaria Sorocaba a Iguape, como mostra a Figura 5. Esse projeto de ferrovia também não foi executado, inviabilizado no Encilhamento.

Quanto aos canhões, o ministro julga importante a fundição de artilharia no Brasil, mas "persuado-me ser do meu dever observar que não convém fundir peças de ferro de menor calibre 79 que o de 12." A afirmação de que à Marinha só interessavam canhões de calibre maior do que 12 libras inviabilizava a possibilidade de Ipanema atendê-la pois, mesmo que os dois altos-fornos fossem operados juntos, não seriam capazes de produzir a quantidade de metal líquido necessária para produzir canhões daquele tamanho. Um canhão inglês de 12 libras e 8 pés de comprimento, que era usado em fragatas, pesava três toneladas e meia. ${ }^{80} \mathrm{~A}$ proposta de Bloem morre ali, naquele parecer. Não foram liberados recursos para a proposta da oficina de Juquiá, nem os canhões foram enviados à Corte. Os canhões, entretanto, viveriam outras peripécias.

O canhão de calibre de 6 libras é hoje parte do acervo do Museu Paulista e os outros dois estão expostos à intempérie na chamada praça dos canhões, no centro da cidade paulista de Sorocaba. Todos aqueles canhões de ferro fundido que podem ser vistos espalhados pelas fortalezas da costa brasileira foram importados. Pelo que se conhece, os únicos fundidos no Brasil são os três canhões aqui citados e dois outros menores, de salva, todos fabricados sob a direção de João Bloem. A fundição da Bahia chegou a fazer algumas armas no século XVII e - Arsenal de Guerra do Rio de Janeiro também fundiu umas poucas peças em 1820. Entretanto, o trabalho de fundição de bocas de fogo só se tornou comum no período da Guerra do Paraguai, tanto no Arsenal de Guerra quanto no de Marinha, mas todas essas armas eram de bronze, um material que dependia de instalações menos complexas para ser trabalhado.
75. Cf. Andrada (1805).

76. WOLPERT, H. Estrada Itapetininga-Juquiá: 140 anos de gastanças públicas. No prelo.

77. Rath (1857).

78. Cf. Mursa (1875)

79. O calibre 12, projétil de $5,5 \mathrm{~kg}$, era considerado como o mínimo utilizável em embarcações oceânicas.

80. Cf. Caruana (1984) 
81. Cf. Paranhos Junior (1872).

82. Cf. Pinto (1845).

83. Cf. Souza (1885)

84. Cf. Almeida (1949).

85. Almeida (1944, p. 84); cf. Felicíssimo (1969).
No Rio de Janeiro, o Arsenal de Guerra nunca fundiu canhões de ferro nem nunca pretendeu fazer. ${ }^{81}$ Isso vale também para o Arsenal de Marinha Imperial, ainda que tivesse uma fundição de ferro. No contexto da época, o fato de o ministério não ter aceitado a oferta de Bloem faz algum sentido: havia centenas de canhões Blomefield em reserva no Arsenal de Marinha. Um relatório do Ministério da Marinha, de 1845, lista 849 canhões de ferro em depósito, apenas no Arsenal do Rio de Janeiro. Desses, apenas 103 eram dos calibres 9, 6 e 4 - apenas quatro eram de calibre 4 libras, mostrando como esses calibres eram pouco usados. $\bigcirc$ tipo mais comum era o canhão de 24 libras, com 284 peças em depósito. ${ }^{82}$ Quando o Exército resolveu reformar o sistema de defesa, em 1850 e, depois, em 1861, optou pelas peças Blomefield da Marinha.

Havia também o problema dos calibres mencionados: 4, 6 e 9, podendo chegar a 12. São todos calibres pequenos, de uso limitado em fortificações, sendo que os canhões de ferro não eram usados na artilharia de campanha por causa do peso maior do material. Só o de calibre 12 teria alguma utilidade contra navios. Os outros só servem para defesa terrestre, o que não era comum aqui no Brasil, porque as fortificações brasileiras são de defesa costeira e, mesmo assim, o sistema colonial de fortes tinha sido desativado ${ }^{83} \mathrm{em} 1831$. Os canhões usados nos fortes foram abandonados para enferrujar. Em caso de necessidade, era só apanhar os materiais em um forte desativado. As peças propostas seriam mais úteis à Marinha, em que poderiam ser usadas em barcos e navios pequenos. Mas a Marinha tinha uma imensa reserva de canhões.

No plano da políitica, quando os liberais foram derrubados, em março de 1841, Bloem continuou tentando agradar os ministros e o imperador. Uma das obras realizadas no ano seguinte foi o Portão da Coroação (Figura 6), com data de 18 de julho de 1841. Os canhões, desprezados pelo ministério, ficaram na fábrica de lpanema.

Em 1842, Tobias de Aguiar e o senador Diogo Antônio Feijó deflagraram a Revolta Liberal, no dia 17 de maio. Sorocaba foi o centro da revolta paulista. No dia 23 de maio, Tobias mandou buscar material bélico na Fábrica. Na relação dos objetos retirados constam 84 "quatro peças de artilharia de ferro, a saber: uma de calibre 6 reforçado em calibre 9, uma de calibre 6 , uma de calibre 4 reforçada, todas de bateria, e uma de calibre 3 para salvas, além de 40 balas de calibre 4".

Um dos historiadores da revolta liberal foi Aluísio de Almeida, pseudônimo do padre Luís Castanho de Almeida. No livro sobre esse episódio, publicado em 1944, ele comete um engano ao descrever a cena da entrega dos canhões por Bloem aos revoltosos, ${ }^{85}$ que vários cronistas passaram a repetir: 
Numa daquelas noites frias de maio apeou um cavaleiro embuçado à porta do "Palácio do Governo". Queria falar com o coronel. Era o sargento-mor João Bloem e foi reconhecido por mais de um curioso. No dia seguinte, um pequeno grupo de liberais armados tomou o rumo para a Fábrica de Ferro de São João do Ipanema e fez alto frente ao portão grande. À esquerda, no primeiro pavilhão, estava uma porta de ferro fundido com a homenagem ao imperador e ao Exmo. Senhor Tobias, então presidente de São Paulo, no primeiro aniversário da maioridade, 23 de julho de 1841. A mesma data e o nome de Pedro II, sem o de Tobias, traziam os três canhõezinhos. ${ }^{86}$

A data inscrita nos canhões é 23 de julho de 1840, como se pode ver hoje, na praça dos canhões, em Sorocaba. Esse engano de Aluísio de Almeida levou muitos historiadores a crer que os canhões também foram fundidos na mesma data em que o portão que fecha um dos edifícios da Fábrica (Figura 6), homenageando a coroação de Pedro II, quase um ano depois da declaração da maioridade. As cartas de Bloem aqui citadas não deixam dúvida de que os canhões foram fundidos em agosto de 1840 e homenageiam a declaração da Maioridade.

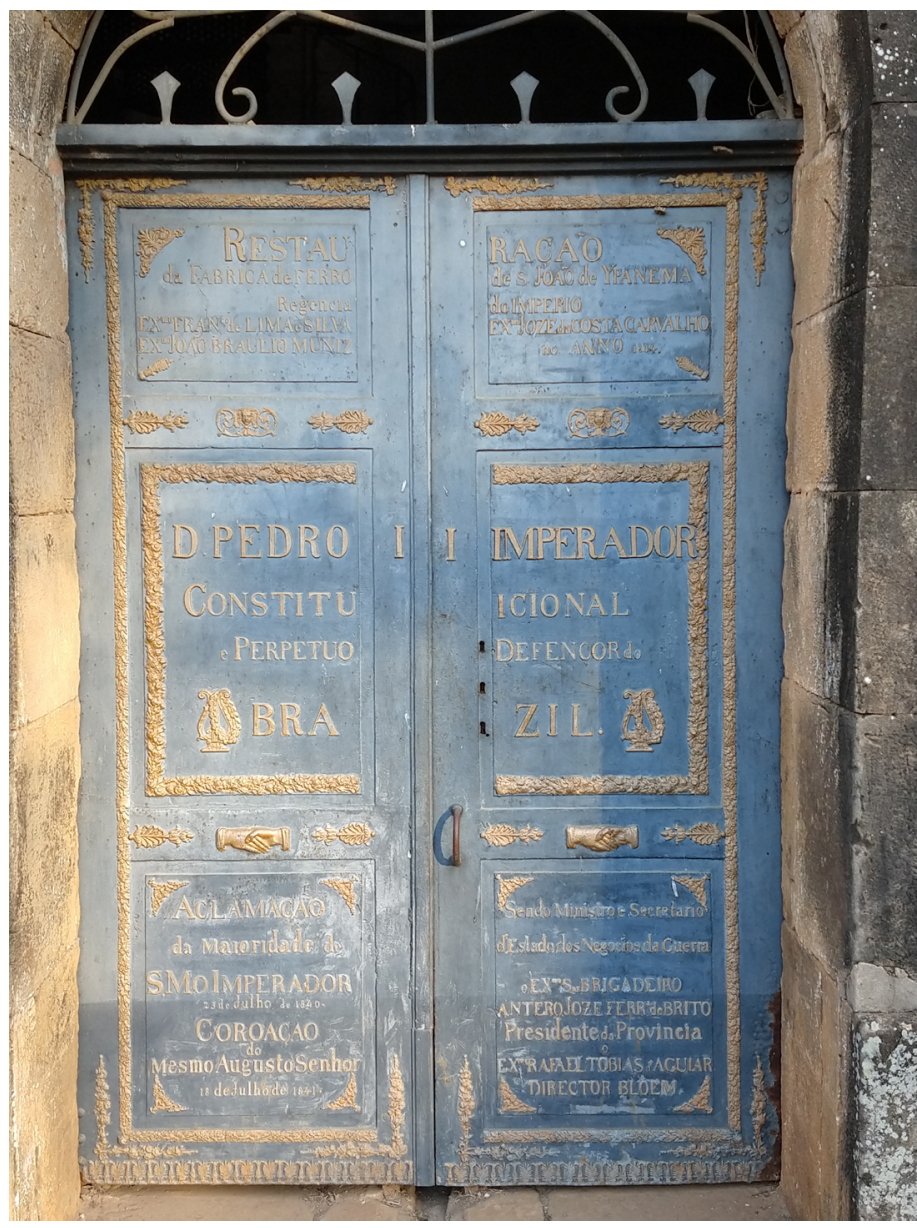

Figura 6 - Portão da Coroação, também fundido por João Bloem, datado de 1841. Fonte: Foto de Luciano Regalado (2019). 
88. Cf. Sentinella da Monarchia (1842a).

89. Sousa (2015) liga o jornal a Vasconcelos, o mesmo Senador que, em 1840, criticou o apoio do ministério liberal à Ipanema.

90. Sentinella da Monarchia (1842b).
Os canhões foram levados até a praça que era o quintal da casa da mãe de Rafael Tobias de Aguiar e ficou conhecida como Praça da Artilharia. ${ }^{87}$ Por um tempo o local teve o nome da mãe dele, Largo de Dona Gertrudes, e, hoje, é a praça Doutor Artur Fajardo, mais conhecida como "largo dos canhões", pois as duas peças estão lá.

Como a capital da província não se rebelou como esperava Tobias, batalhões revoltosos foram encaminhados para conquistála. Não obstante haver afirmações de que pelo menos um canhão teria sido levado por essas forças, Aluísio de Almeida não dá fé à essa ideia. As tropas chegaram até o rio Pirajussara, nas proximidades da ponte do rio Pinheiros, no dia 8 de junho, mas, de lá, recuaram após encontrar tropas do barão de Caxias. No dia 20 de junho de 1842, as tropas governamentais entraram em Sorocaba, mas Tobias de Aguiar iá havia fugido e Feijó foi preso.

Bloem ficou numa situação difícil, ao fim da revolta. Consta que ele encontrou Caxias no dia 20, horas antes da entrada em Sorocaba. Caxias deu ordem para que ele perseguisse e prendesse Tobias. ${ }^{88}$ Bloem buscou-o nas redondezas, sem sucesso, e retornou à Fábrica em julho. Tobias só foi preso em novembro daquele ano, no Rio Grande do Sul. Na Corte, o jornal Sentinella da Monarquia, ligado ao senador Bernardo Vasconcelos, 89 conservador, fez graves críticas pessoais a Bloem, acusando-o de ter ajudado Tobias antes da chegada de Caxias, de ter comportamento duplo, de ser um "administrador rico de uma administração pobre" e de ser um absurdo que Bloem fosse encarregado de perseguir Tobias:

mas como poderia ser preso Tobias se o Exmo. General foi iludido na confiança que depositou no major Bloem a quem encarregou de sua captura? Como poderia ser preso o chefe dos rebeldes de São Paulo sendo o major Bloem o incumbido de prendê-lo? O major Bloem? Que benigno astro teria presidido ao seu nascimento ou a sua chegada ao Brasil? Destituído de préstimo, de conhecimentos, não tendo outro merecimento que alguma atividade, e esta mesma empregada em proveito individual, que de ordinário é avesso aos interesses públicos, como todos compreendem, tem obtido todavia tal consideração que se the tem conferido empregos de grande importância e comissões de alta consequência, cujo desempenho tem sido como ninguém ignora, e tal é sua feliz estrela que tem sido conservado nesses empregos, e ainda mais premiado como bom serventuário da nação. ${ }^{90}$

Aluísio de Almeida afirma que Caxias escreveu ao presidente da província, Costa Carvalho, para "que substituísse Bloem, por não andar às boas nem com - Freitas, de Tatuí, nem com Carlos Augusto Oliva, comandante de Sorocaba". 
Além disso, Henrique Godivino [seguramente o ex-diretor Godwin], demitido do emprego na Fábrica, denunciou o diretor como revoltoso ao sucessor de Costa Carvalho. ${ }^{91}$ Bloem resistiu às primeiras pressões, mas, em setembro de 1842, entregou o cargo na Fábrica. Sua "fé de ofício", documento que sintetiza a carreira militar de um oficial, registra:

Em ofício do quartel-general de vinte e cinco de novembro do dito ano [1842] foi ordenada a prisão deste oficial por participações e de ter tomado parte na rebelião de São Paulo, a fim de se justificar. [Foi] recolhido preso à fortaleza de Santa Cruz. Foi desligado do Corpo de Engenheiros. [A] seis de [maio de 1843] se determinou que fosse metido em conselho de guerra para responder à acusação de tomar parte na rebelião de São Paulo. Por unanimidade de tenções foi absolvido, por não se provarem os artigos de acusação. Foi solto a nove [de dezembro de 1843]. Por decreto de oito de janeiro de 1844 ficou pertencendo à primeira classe do Exército na respectiva arma. ${ }^{92}$

Na documentação sobre a revolta, publicada no livro de João Baptista Moraes, ${ }^{93}$ Revolução de 1842, são citados os nomes de dez pessoas que foram presas ao final da revolta, incluindo Feijó e Vergueiro, mas não inclui o nome de Bloem. Aluísio de Almeida afirma, ${ }^{94}$ em defesa de Bloem, que ele escreveu cartas seguidas ao presidente da província, tanto antes quanto depois do dia 17 de maio de 1842.

Bloem escreveu um longo artigo no Diário do Rio de Janeiro, em junho de 1843, no qual defende a administração da fábrica, sem qualquer menção à Revolta. ${ }^{95}$ Note-se que Tobias de Aguiar continuava preso e só seria anistiado em 1844. Em 27 de março de 1844, João Bloem foi promovido a tenente-coronel, situação ironizada pelo jornal $\bigcirc$ Brasil, numa nota intitulada

\footnotetext{
Pergunta inocente: na lista dos agraciados aparece o nome de um militar Bloem: quem será esse senhor? Será o mesmíssimo diretor do lpanema que ainda outro dia foi processado por haver quanto em si coube coadjuvado os esforços dos Fidelíssimos? Não pode ser porque nesse caso deveria o senhor Tobias estar marquês de Sorocaba, o senhor José Feliciano marquês de Cocaes e o senhor Ottoni duque de Paraibuna. Quem será pois? Afirmam que é ele próprio e que o resto dos despachos ficou para o dia 25 de março. ${ }^{96}$
}

Tobias, Feliciano e Ottoni foram os derrotados líderes da Revolta Liberal e estavam presos, naquele momento. ${ }^{97}$ Em julho de 1844, Bloem partiu para Sergipe, trabalhou em várias obras da capital e deixou como legado um mapa do Estado. Mais tarde foi para o Rio Grande do Sul, onde faleceu em 1851.
91. Almeida (1944, p.84).

92. Exército Brasileiro (1851).

93. Moraes (1908).

94. Almeida (1949).

95. Bloem (1843).

96. Pergunta... (1844).

97. Cf. O Brazil (1843) 
98. Santos (2009).

\section{Ibid.}

100. Brasil. Ministério da Guerra. Relatório apresentado pelo Ministro da Guerra à Assembleia Geral legislativa, 1842 apud Santos (2009).

101. Mursa (1875).

102. Dupré (1885).

103. Calógeras (1905)
No livro A fábrica de ferro São João de Ipanema: economia e política nas últimas décadas do segundo reinado, Nilton Pereira dos Santos chamou a atenção para outro problema da administração Bloem.

\begin{abstract}
Analisando os dados referentes ao ano de 1835, é possível constatar que os parâmetros utilizados pela contabilidade distorceram um pouco a real situação da fábrica. Da renda total de 20 contos de réis, 6,9 contos eram fruto de trabalhos e aparelhos confeccionados para uso no próprio estabelecimento, mas computados como renda, como minerais extraídos, o carvão usado. Se a contabilidade fosse refeita apresentaria um déficit de 3,7 contos, ao invés do saldo de 3,2 contos. ${ }^{98}$
\end{abstract}

Essa confusão se repete no balanço do ano contábil 1839-1840. Quando Bloem pedia apoio do ministério para agregar mais mão de obra escrava ou para pagar a incorporação dos terrenos vizinhos à fábrica para, com isso, aumentar a produção de carvão, ele fazia previsões irrealistas de receita anual. Santos aborda essa questão pelo lado da demanda, fundamentando a crítica com base nas "reduzidas dimensões do mercado interno, a dificuldade existente com o transporte e a distância dos principais centros urbanos do período". 99 É possível complementar a crítica com base na capacidade produtiva dos fornos. Mesmo se tivesse os escravizados e o carvão, seria árduo que aqueles fornos produzissem mais do que quinhentas toneladas anuais e se $90 \%$ resultassem em obras modeladas, a 1920 réis a arroba, resultaria em 58 contos anuais, bem longe dos 400 contos anuais que ele prometia em 1842, caso as condições fossem atendidas. ${ }^{100}$

De certa maneira, os aspectos aqui apresentados sobre as proposições de Bloem toldam a visão positiva que a historiografia tem mantido sobre ele. $O$ coronel Mursa, diretor de lpanema trinta anos depois da saída de Bloem, registrou que ele foi "o único diretor que, depois de Varnhagen, obteve o apoio e os meios necessários para desenvolver os trabalhos desta fábrica". ${ }^{101}$ Leandro Dupré, engenheiro da Escola de Minas de Ouro Preto, que trabalhava em Ipanema, publicou um artigo ${ }^{102} \mathrm{em}$ que afirma ser "Bloem o encarregado da restauração, o que executou com grande sucesso". Pandiá Calógeras que, aos 25 anos, escreveu uma série de artigos que levou ao fechamento de lpanema, registrou, mais tarde, que "Bloem levou [a reorganização da Fábrica] a efeito com inteiro sucesso". ${ }^{103}$ Jesuíno Felicíssimo (1969), autor muito citado sobre Ipanema, afirmou que quando Bloem tomou posse, a atividade aumentou e os negócios tomaram novo seguimento. Macedo Soares (1972), o fundador da Companhia Siderúrgica Nacional legítima "filha" de Ipanema - afirma, em um artigo sobre a história da siderurgia no Brasil, que Bloem "estava trabalhando duramente e com acerto quando foi 
afastado do posto". Faciaben (2012), numa dissertação de mestrado da USP, marcou um processo de restauro da fábrica e um progressivo aumento de eficiência e produtividade". Santos (2009) foi o único a tirar a administração do foco, ao escrever que "a fábrica teve um período de prosperidade entre 1836 e 1842, favorecido pela expansão da lavoura canavieira no interior paulista".

Analisando os dados de produção, a média de 150 toneladas anuais não seria considerada boa. $\bigcirc$ que diferenciou Bloem, como disse Mursa, foi ter obtido apoio do governo para investir; e ter ficado em lpanema por sete anos, quando os colegas militares que se sucediam na direção não ficavam mais do que dois anos. Dirigir lpanema devia ser difícil, sempre dependendo de mais dinheiro do governo. Talvez isso explique as promessas exageradas de Bloem, tentando convencer a Corte de que valeria a pena investir em lpanema ou de que era possível resolver com facilidade os obstáculos, como foi no projeto Juquiá. Um dos legados de Bloem foi ter trazido à Fábrica o mestre de fundição Frederico Holtz que, 30 anos depois, ajudou Mursa a contratar uma nova leva de metalúrgicos para lpanema. $\bigcirc$ outro legado, quase indelével, foi ter deixado o nome gravado nos canhões.

Os canhões ficaram em Sorocaba. Houve ordem de se quebrarem os munhões, que são as partes cilíndricas, transversais ao eixo do canhão, que servem de apoio e permitem o ajuste do ângulo de tiro. Sem munhão, seu uso seria impossível. Como se pode perceber nos três canhões, essa quebra não foi realizada. $\bigcirc$ mais provável é que foram só encravados os ouvidos.

De 1896 até 1926, os canhões permaneceram encravados no solo, de culatra voltada para cima, guarnecendo ângulos ou esquinas do jardim que existiu na atual praça Frei Baraúna, chamado "Jardim dos Bichos" desde 1914, porque ali existiam animais cercados como se fosse um jardim zoológico. Uma reportagem de 1960 afirma que "desencravados os quatro canhões, dois deles foram enviados ao Museu Paulista onde se encontram. Os outros dois foram reinstalados na praça Fajardo, em 1935, no antigo largo de Santa Gertrudes, de Sorocaba". 104

Um dos canhões presenciou a reinauguração do Museu Paulista, em 1922. A edição de dezembro de 1922 da revista llustração Brasileira, o órgão oficial da Comissão Executiva do Centenário da Independência, que inclui um artigo de Affonso de Taunay, o registra numa foto, aqui reproduzida na Figura 7, com a legenda "galeria da direita, no andar térreo". No texto do artigo, em certo ponto Taunay refere-se a "um grande canhão fundido no Ypiranga em 1840 e tomado aos revoltosos de 1842, em Sorocaba". ${ }^{105}$ Certamente houve um engano entre "Ypiranga" e "Ypanema". 


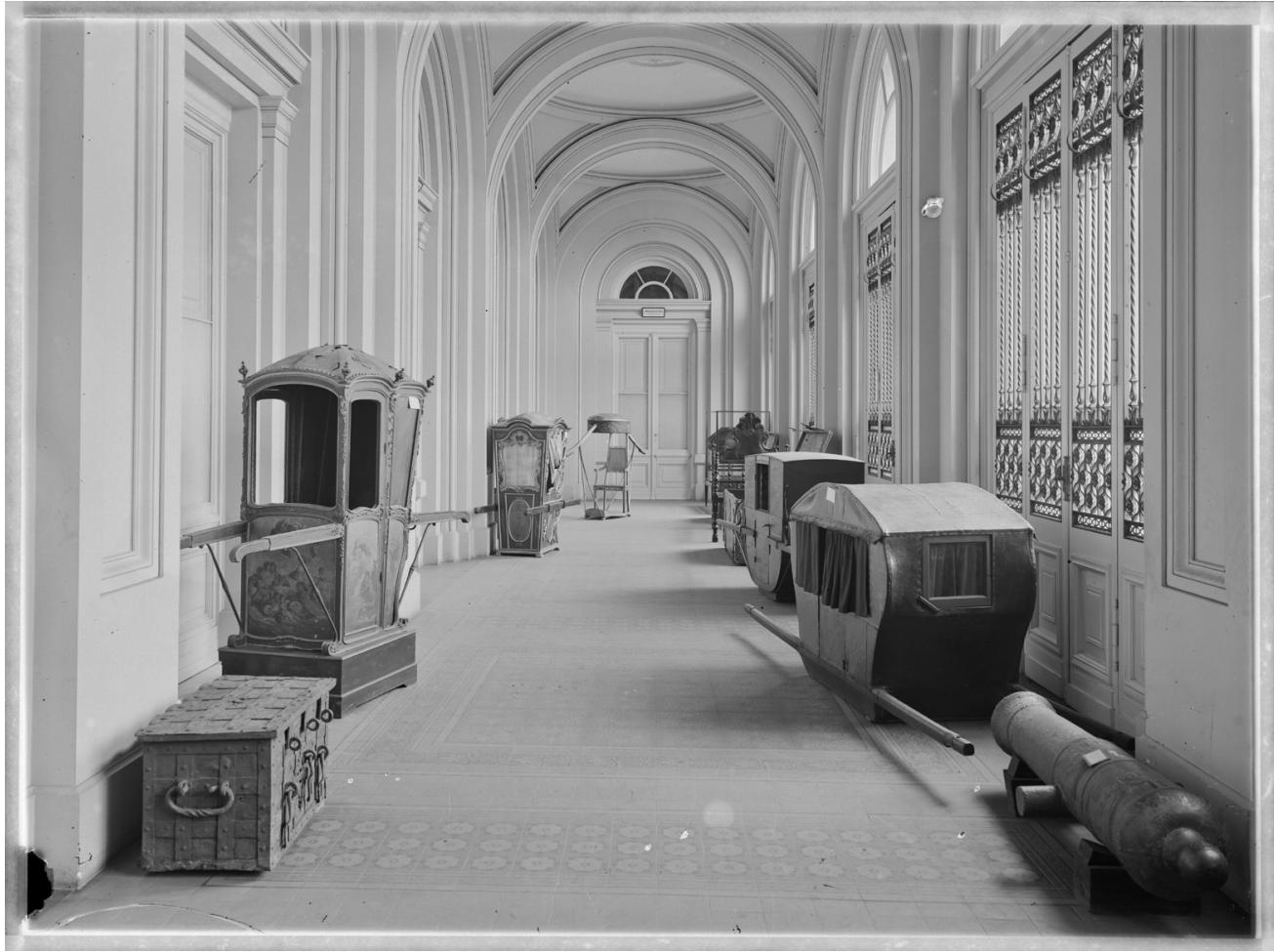

Figura 7 - Fotografia de uma galeria do Museu Paulista exibindo um dos canhões fabricados em Ipanema, em 1922. Acervo: Museu Paulista/ USP.

Ainda não foi encontrada nos arquivos do museu, documentação sobre a entrada daqueles objetos no acervo. Nele há o registro de um canhão com a identificação 1-15-02-03734-00-00, e a menção: "construído pela antiga fábrica de ferro de Ipanema". Entretanto, não é do tipo Blomefield. Por outro lado, faz parte do acervo um outro canhão, identificado pelo código 1-15-02-000-0374100-00, que é do mesmo tipo dos dois canhões de Sorocaba, tem a inscrições 23 de julho de 1840 em relevo, dom Pedro ll e uma letra B. Não há dúvida de que esse é um dos três canhões fabricados por Bloem, até por ter alma de quase 10 centímetros, completando o conjunto (Figura 8). O quarto, que seria um canhão de salva (ou de festim), pode não ser aquele citado nos arquivos do museu, mas isso merece mais investigação. Em 1994, para a comemoração dos 200 anos do nascimento de Tobias de Aguiar, foram retirados os lacres dos dois canhões de Sorocaba e foram disparadas duas salvas comemorativas. ${ }^{106}$ 


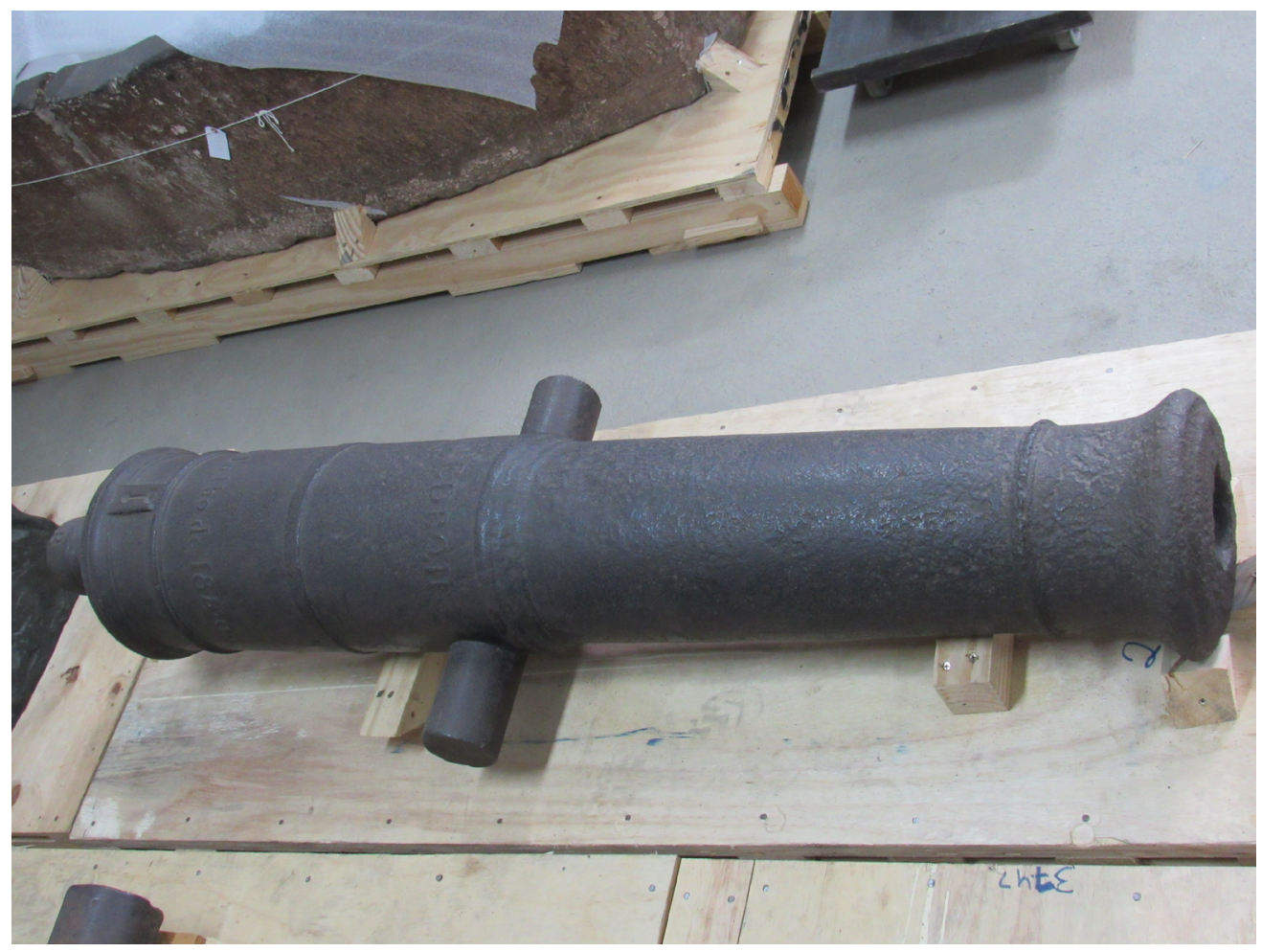

107. Cf. Moura (2014). 108. Cf. Ribeiro (2018)

Figura 8 - Canhão de lpanema no acervo do Museu Paulista. Fonte: Foło de Fernando JG Landgraf.

É possível observar a insurgência do ferro nos inventários do século XIX, ${ }^{107}$ desde $\mathrm{o}$ cotidiano de talheres, panelas de ferro, chapas de ferro fundido para fogões a lenha, ferros de passar roupa, candeeiros, até a presença na arquitetura, nos ornamentos, nas escadas e gradis dos balcões das cidades que se verticalizavam para o segundo e terceiro pisos. Nas ferramentas agrícolas, nas ferraduras para proteção dos cascos dos animais de transporte e nas rodas de vagões, sua onipresença chegava às estradas de ferro e às correntes, grilhões e coleiras que sujeitavam o escravizado negro. Ademais, o ferro ainda estava presente nos tubos que começavam a trazer a água encanada, a levar o esgoto, o gás do telégrafo.

Faz falta redescobrir um dos objetos mais significativos produzido por Ipanema: a moenda de cana, da qual não se conhece nenhum exemplar que tenha sobrevivido. O Museu Paulista teve um exemplar, exibido na Exposição do IV Centenário, em 1954, hoje desaparecido. ${ }^{108}$

A saga dos canhões, de certa maneira, é a saga de lpanema. A competência técnica estava demonstrada, mas a demanda não the era correspondente. A Fábrica continuou operando bem por mais alguns anos, e o prestígio se refletia nas visitas que Pedro Il the fez em 1846, 1878, 1884 e 1886, no entanto, ela não gerava os 
109. Wenceslau Braz Pereira Gomes (1868-1966). Presidente do Brasil entre $1914 \mathrm{e}$ 1918. A Fábrica foi reaberta em 1917, para enfrentar a falta de matéria prima causada pela $1^{\text {a }}$ Guerra Mundial.

110. O alto forno de Ybycuí operou entre 1854 e 1869 , quando foi destruído. Cf. Plá (1976).

111. Cf. Geijerstam (2004).

112. Cf. Yonekura (1994) e IIda (1980). recursos suficientes para seu custeio. Alguém decidiu desmontá-la em 1862, mas outra vez o governo resolveu investir. Trouxeram o coronel Mursa, que a dirigiu por 25 anos, foi à Europa buscar técnicos e novos equipamentos, atendeu às demandas das oficinas de manutenção das ferrovias, mas não conseguiu torná-la rentável. Fechada em 1895, Wenceslau Braz ${ }^{109}$ a reabriv em 1917. Foi definitivamente fechada em 1926.

Apesar do intermitente interesse do governo, não se viabilizou. Mesmo tendo formado mão de obra, nem assim houve empresário que tenha se arriscado a criar uma siderúrgica no Brasil. A bem da verdade, em lugar algum da América Latina, no século XIX, mesmo se incluirmos o alto forno de Ybycui, no Paraguai, cuja construção foi iniciada em 1849 por Henry Godwin, aquele que Bloem trouxe da Inglaterra. ${ }^{110} \mathrm{Nem}$ mesmo na Índia sob o controle inglês. Houve uma tentativa de estabelecer ali duas siderúrgicas em 1860, com recursos do governo, mas em pouco tempo fracassaram. ${ }^{11}$ As primeiras tentativas japonesas, em 1850, também não deram certo do ponto de vista empresarial. ${ }^{112}$

Yonekura cita um relatório governamental sobre as razões do insucesso, e o resumiu em três pontos: suprimento de minério e carvão foi desorganizado; a demanda local por ferro-gusa era pequena; havia falta de acumulação de experiência tecnológica num contexto social mais amplo. Ele acrescentou um outro aspecto: a falta de capital necessário para um empreendimento tão grande, e resumiu: a economia japonesa era pré-moderna.

O estigma do fracasso paira sobre todos os trabalhos publicados sobre Ipanema, e isso aparece também sobre essas tentativas na Índia e no Japão. São feitas listas de causas do fracasso, com três, cinco, sete argumentos. $\bigcirc$ esforço é compreensível, mas com isso esquece-se de vê-los como experimentos heroicos, aos quais é necessário dar mais valor do que se tem dado. A luta de seus criadores ou, no caso de lpanema, de gerações de diretores, para manter em operação os altos fornos, produzir ferro-gusa, peças fundidas e barras forjadas, usando a melhor literatura disponível, a nascente ciência para vencer os desafios técnicos e para demonstrar que era possível produzir ferro de qualidade comparável ao europeu, e que era possível operar com regularidade o que talvez tenha sido o mais complexo dos empreendimentos industriais daquele momento.

Entrando no século XX, a oportunidade e o desafio siderúrgico foram visualizados por muitos. Era tratado politicamente o Problema Siderúrgico Nacional. A importação de ferro e aço chegou a ser 10\% do valor da importação anual brasileira, entre 1935 e 1942. Somente em 1942 a tecnologia, a indústria, a logística e a política se conjuminaram, na criação da CSN. O que em Ipanema foi sonhado, realizou-se. 


\section{AGRADECIMENTOS}

Os autores agradecem a Adolfo Frioli por importantes informações, referências e fotografias e a Renato Schroeder pela edição do texto. 


\section{REFERÊNCIAS}

FONTES MANUSCRITAS

ALBUQUERQUE, Francisco de Paulo Cavalcante de. Ofício a João Bloem. Rio de Janeiro: Arquivo Nacional. Série guerra IG5 18, pasta 1840, 20 set. 1840.

BLOEM, João. Ofício ao Barão de Itapicuru. Rio de Janeiro: Arquivo Nacional. Série guerra IG5 18, pasta 1835, 28 jun. 1835.

BLOEM, João. Carta e Proposta enviadas ao Ministro da Guerra Manoel da Fonseca Lima e Silva. Rio de Janeiro: Arquivo Nacional. Série guerra IG5 18, pasta 1836, 4 jun. 1836.

BLOEM, João. Carta enviada ao Ministro dos Negócios da Guerra, Sebastião do Rego Barros, de Elberfeld, Alemanha. Rio de Janeiro: Arquivo Nacional. Série Guerra IG5 18, pasta 1838, 23 fev. 1838.

BLOEM, João. Rio de Janeiro: Arquivo Nacional. Série guerra IG5 18, pasta 1839. 1 mar 1839.

BLOEM, João. Carta de Bloem ao Ministro e Secretário de Estado dos Negócios da Guerra, Sr. Sebastião do Rego Barros. Rio de Janeiro: Arquivo Nacional. Série guerra IG5 18, pasta 1839. 7 mar. 1839.

BLOEM, João. Ofício ao ministro da Guerra, Francisco de Paulo Cavalcante de Albuquerque. Rio de Janeiro: Arquivo Nacional, série guerra IG5 18, pasta 1840. 18 ago. 1840a.

BLOEM, J. Ofício ao Ministro Secretário d'Estado dos Negócios da Marinha, Jacintho Roque de Sena Pereira. Rio de Janeiro: Arquivo Nacional. Série guerra IG5 18, pasta 1840. 27 abr. 1840b.

BLOEM J. Ofício ao Ministro Secretário d'Estado dos Negócios de Guerra, Conde de Lages. Rio de Janeiro: Arquivo Nacional. Série guerra IG5 18, pasta 1840. 27 abr. 1840d.

BLOEM J. Ofício ao Ministro, Diretor de Estado dos Negócios Da Guerra, Francisco de Paulo Cavalcante de Albuquerque. Rio de Janeiro: Arquivo Nacional. Série guerra IG5 18, pasta 1840. 18 ago. $1840 \mathrm{e}$.

BLOEM, J. Ofício ao Regente do Império Pedro de Araújo Lima. Rio de Janeiro: Arquivo Nacional. Série guerra IG5 18, pasta 1840. 16 jul. $1840 f$.

BLOEM, J. Relação dos cilindros fundidos e vendidos para engenhos de açúcar no tempo da administração do Major Bloem, de fins de abril de 1834 a junbo de 1841. Rio de Janeiro: Arquivo Nacional. Série guerra IG5 18, pasta 1841. 22 jun. 1841. 
EXÉRCITO BRASILEIRO. Fé de Ofício de João Bloem. Rio de Janeiro: Arquivo Histórico do Exército, 1851.

OLIVEIRA, Francisco Antonio. Carta ao presidente da província de São Paulo, Bernardo Gavião Peixoto. Rio de Janeiro: Arquivo Nacional. Série guerra IG5 18, pasta 1840. 9 set. 1837.

SAGALSOVA, Francisco Candido, Almoxarife de Ipanema. Conhecimento de carga. Ipanema, 9 de maio de 1837. Arquivo Nacional.

FONTES IMPRESSAS

ALMEIDA, Aluísio de. Bloem e a Revolução Liberal. O Estado de S. Paulo, São Paulo, 19 nov. 1949 .

ANAIS DO SENADO. Anno de 1840. Rio de Janeiro: Senado Imperial, 1840. t. 6. Disponível em: <https://bit.ly/3kv2whc>. Acesso em: 25 ago. 2021.

BLOEM, João. Carta publicada aos 19 de maio de 1840. Correio Official, Rio de Janeiro, 1840c.

BLOEM, João. Fábrica de S. João de Ypanema. Diário do Rio de Janeiro, Rio de Janeiro, n. 144, 3 jul. 1843.

CASTRO, Adler Homero Fonseca de; ANDRADE, Ruth Beatriz S. C. O pátio dos canbões: seu histórico e acervo. Rio de Janeiro: Museu Histórico Nacional, 1993. Mimeografado.

DISPAROS de canhões abrem festividades a Tobias. O Cruzeiro do Sul, Sorocaba, 5 out. 1994.

GUTIERRES, J. Relatório apresentado à Assembleia Geral Legislativa na segunda sessão da oitava legislatura, pelo Ministro e Secretário de Estado dos Negócios da Guerra, Manoel Felizardo de Sousa e Mello, 1850. Rio de Janeiro: Ministério da Marinha, 1850.

NESTAS PARAGENS, há cento e vinte e cinco anos... Correio Paulistano, São Paulo, n. 28044, p. 16,7 set. 1947.

O BRAZIL. Rio de Janeiro. Rio de Janeiro, p. 4, 15 set. 1842.

PARANHOS JUNIOR, José Maria da Silva (Visconde do Rio Branco). Relatório apresentado à Assembleia Geral Legislativa na quarta sessão da décima quarta legislatura pelo secretário de Estado interino dos Negócios da Guerra, visconde de Rio Branco. Rio de Janeiro: Laemmert, 1872.

PERGUNTA innocente. O Brasil, [s. l.], ed. 516, 1844. 
PINTO, Maria José da Silva. Demonstração da receita e despesa existente dos gêneros da primeira seção do almoxarifado da Marinha até o fim de fevereiro do corrente ano. Rio de Janeiro: Laemmert, 1845.

SCHÜCH, Guilherme (Barão de Capanema). O Brasil e a Inglaterra. Diário do Rio de Janeiro, Rio de Janeiro, n. 18, 18 jan. 1863.

SENTINELLA DA MONARCHIA. (a) Rio de Janeiro: [s. n.], n. 223, p. 4, 22 jul. 1842.

SENTINELLA DA MONARCHIA. (b) Rio de Janeiro: [s. n.], n. 244, p. 3, 16 set. 1842.

SUTIL, Miguel. Os canhões do novo jardim. Cruzeiro do Sul, Sorocaba, 26 mar. 1936.

TAUNAY, Afonso d'Escragnolle. O Museu Paulista. Illustração Brasileira, Rio de Janeiro, n. 28, 25 dez. 1922.

VILLIERS DE L'ILE-ADAM, J. de. (Visconde). Carta Topographica da Provincia de São Paulo. 1 mapa: 49,5 × $62 \mathrm{~cm}$. Litografado. Rio de Janeiro: Biblioteca Nacional do Rio de Janeiro, 1847. Disponível em: <https://bit.ly/3BgRJOn>. Acesso em: 25 ago. 2021.

LIVROS, ARTIGOS E TESES

ALMEIDA, Aluísio de. Achegas à história do sul paulista. Revista do Arquivo Municipal, São Paulo, v. 135-140, p. 183, 1950.

ALMEIDA, Aluísio de. A revolução liberal de 1842. Rio de Janeiro: Livraria José Olympio, 1944.

ANDRADA, Martim Francisco Ribeiro de. Diário de uma viagem mineralógica pela Província de São Paulo no ano de 1805. In: CLETO, Marcelino Pereira et al. Roteiros e notícias de São Paulo colonial (1751-1804). São Paulo: Governo do Estado de São Paulo, 1977. p. 143-160.

ARAUJO, Paulo Eduardo Martins et al. Evolução do perfil interno dos altos fornos brasileiros do século XIX. In: SEMINÁRIO DE REDUÇÃO DE MINÉRIO DE FERRO, 47., 2017, São Paulo. Anais [...]. São Paulo: ABM, 2017.

AYMARD, Jacques-Marie (conde de Gestas). Memoria sobre o estado actual da industria na cidade do Rio de Janeiro e lugares circumvisinhos. O Auxiliador da Industria Nacional, Rio de Janeiro, n. 1, 1837.

BAKER, Thomas. Elements of mechanism elucidating the scientific principles of the practical construction of machines. London: John Weale, 1852. 
BARROS, Gustavo. O desenvolvimento do setor siderúrgico brasileiro entre 1900 e 1940: Crescimento e substituição de importações. Estudos Econômicos, São Paulo, v. 45, n. 1, p. 153183, 2015. Doi: <https://doi.org/10.1590/0101-4161201545153gbs>.

CALÓGERAS, João Pandiá. A Fábrica de Ferro de São João de Ipanema. Revista Brazileira, ano 1, t. 1 , p. $83-95$, p. $179-186$, p. 290-300, t. 2, p. 90-100, p. 212-227, 1895.

CALÓGERAS, João Pandiá. O ferro: ensaio de história industrial. Revista do IHGB de SP, São Paulo, v. 9, p. 20-100, 1904.

CARUANA, Adrian. The identification of British Muzzle Loading Artillery: part 2, the piece. The Canadian Journal of Arms Collecting, [s. l.], v. 22, n. 1, 1984.

CASTRO, Adler Homero Fonseca de. A pré-indústria e governo no brasil: iniciativas de industrialização a partir do arsenal de guerra do Rio de Janeiro, 1808-1864. 2017. Tese (Doutorado em História Comparada) - Universidade Federal do Rio de Janeiro, Rio de Janeiro, 2017.

COIMBRA, Creso. Visão histórica e análise conceitual dos transportes no Brasil. Rio de Janeiro: Cedop do Ministério dos Transportes, 1974.

DANIELI NETO, Mario. Escravidão $e$ indústria: um estudo sobre a Fábrica de Ferro de São João de Ipanema - Sorocaba (SP) 1765-1895. 2006. Tese (Doutorado em Desenvolvimento Econômico) - Instituto de Economia, Universidade Estadual de Campinas, Campinas, 2006.

DUPRÉ JUNIOR, Leandro. Memória sobre a Fábrica de Ferro de São João do Ipanema. Annaes da Escola de Minas de Ouro Preto, Mariana, n. 4, p. 37-68, 1885.

ESCHWEGE, Wilhelm Ludwig. Pluto brasiliensis. São Paulo: Edusp, 1979.

FACIABEN, Marcos Eduardo. Tecnologia siderúrgica no Brasil no século XIX: conhecimento e técnica na aurora de um país (O caso da fábrica de Ferro de São João de Ipanema). 2012. Dissertação (Mestrado em História Social) - Universidade de São Paulo, São Paulo, 2012.

FELICÍSSIMO, Jesuino. História da siderurgia de São Paulo, seus personagens, seus feitos. São Paulo: Instituto Geográfico e Geológico de São Paulo, 1969.

FERRAND, Paul. A indústria do ferro no Brasil. Annaes da Escola de Minas de Ouro Preto, Mariana, n. 4, p. 122-139, 1884.

GAMA, Ruy. História da técnica e da tecnologia: textos básicos. São Paulo: Edusp, 1985. 
GEIJERSTAM, Jan. Landscapes of technology transfer: Swedish ironmakers in India, 1860-1864. Stockholm: Jernkontorets Bersghistoriska, 2004.

IIDA, Kenichi. Origin and development of iron and steel technology in Japan. Japan: The United Nations University Press, 1980.

JUNQUEIRA, Eulalia. Arte francesa do ferro no Rio de Janeiro. Rio de Janeiro: Memória Brasil, 2005.

KARSTEN, Carl Johann Bernhard. Manuel de la métallurgie du fer. Charleston: Nabu, 2011.

KÜHL, Beatriz Mugayar. Arquitetura do ferro e arquitetura ferroviária em São Paulo. Cotia: Ateliê, 1998.

LANDGRAF, Fernando José Gomes. O colar de ferro da imperatriz. Revista ABM, São Paulo, v. 77, n. 656, 2020. Disponível em: <https://bit.ly/3Dlb3vM>. Acesso em: 25 ago. 2021.

LANDGRAF, Fernando José Gomes; ARAÚJO, Paulo Eduardo Martins; SCHROEDER, Renato. Ipanema e os alemães. In: KUPFER, Eckhard et al. (orgs.). Martius-Staden-Jabrbuch n. 61. São Paulo: Instituto Martius-Staden, 2016. p. 164-177.

LAVERY, B. Carronades and Blomefield Guns. In: SMITH, Robert D. (ed.). British Naval Armaments. London: Royal Armouries, 1989. p. 24.

LIMA, Solange Ferraz. O trânsito dos ornatos. Modelos ornamentais da Europa para o Brasil, seus usos (e abusos?). Anais do Museu Paulista, São Paulo, v. 16, n. 1, p. 151-199, 2008. Doi: <https://doi.org/10.1590/S0101-47142008000100005>.

LOVALlO, Dan; KAHNEMAN, Daniel. Delusions of optimism: how optimism undermines executive's decisions. Harvard Business Review, Boston, v. 81, n. 7, p. 56, 2003.

MAMANI-CALCINA, Elmer Antonio; LANDGRAF, Fernando José Gomes; AZEVEDO, Cesar Roberto de Farias. Investigating the provenance of iron artifacts of the Royal Iron Factory of São João de Ipanema by hierarchical cluster analysis of EDS microanalyses of slag inclusions. Materials Research, São Carlos, v. 20, p. 119-129, 2016. Doi: <https://doi.org/10.1590/19805373-MR-2016-0444>.

MEDEIROS, Francisco Luís Abreu. Curiosidades brasileiras. Itu: Ottoni, 2009.

MORAES, João Baptista. Revolução de 1842. Revista do IHGB de SP, São Paulo, v. 12, 1908. 
MOURA, Carlos Eugenio Marcondes; LANNA, Ana Lúcia Duarte (orgs.). Fazendas de café do vale do Paraíba: o que os inventários revelam. São Paulo: Condephaat, 2014.

OLIVEIRA, Franciely da Luz. Forjando "máquina grande" nos sertões do atlântico: dimensões centro-africanas na história da exploração das minas de Ipanema e na instalação de uma real fábrica de ferro no morro do Araçoiaba (1597-1810). 2020. Dissertação (Mestrado em História) - Universidade Estadual de Campinas, Campinas, 2020.

PLA, Josefina. The British in Paraguay 1850-1870. Oxford: Richmond, 1976.

RATH, Carlos. Fragmentos geológicos e geográficos. São Paulo: Typographia Imparcial, 1857. Disponível em: <https://bit.ly/3gwmZkv>. Acesso em: 13 set. 2020.

RIBEIRO, David William Aparecido. Uma exposição para o IV Centenário de São Paulo: um historiador português narra a "história bandeirante". Anais do Museu Paulista, São Paulo, v. 26, 2018. Doi: <https://doi.org/10.1590/1982-02672018v26e23>.

RIBEIRO, Mariana Alice Pereira Schatzer. Entre a fábrica e a senzala: um estudo sobre o cotidiano dos africanos livres na Real Fábrica de Ferro São João do Ipanema - Sorocaba - São Paulo (1840-1870). São Paulo: Alameda, 2016.

ROBINS, Benjamin. New Principles of Gunnery. [S. l.]: General Books LLC, 2009.

RODRIGUES, João Lourenço. Apontamentos para a história do Ipanema. Boletim do Departamento do Arquivo do Estado de São Paulo, São Paulo, v. 11, 1953.

RODRIGUES, Jorge. Ferro, trabalho e conflito: os africanos livres na Fábrica de Ipanema. História Social, n. 4-5, p. 29-42, 1997.

SANTOS, Irina Aragão. Rendas de ferro: uma doação pela memória civilizatória brasileira. Anais do Museu Paulista, São Paulo, v. 29, p. 1-26, 2021. Disponível em: <https://bit. ly/3krz0sm>. Acesso em: 25 maio 2021.

SANTOS, Nilton Pereira. A fábrica de ferro São João de Ipanema: economia e política nas últimas décadas do Segundo Reinado (1860-1889). 2009. Dissertação (Mestrado em História) - Universidade de São Paulo, São Paulo, 2009.

SCULLY, William. Brazil, its provinces and chief cities, the manners and customs of the people: agriculture, commercial and other statistics taken from the latest official documents, with a variety of useful and entertaining knowledge, both for the merchant and the emigrant. London: Murray \& Co, 1866. 
SIMÕES, Ana, CARNEIRO, Ana, DIOGO, Maria Paulo (eds.). Travels of learning: a geography of science in Europe. New York: Springer, 2003.

SOUZA, Augusto Fausto de. Fortificações do Brasil. Revista Trimestral do Instituto Histórico e Geográfico Brasileiro, t. 48, parte II, 1885.

SOUZA, Irineu Evangelista. Autobiografia: Visconde de Mauá. Brasília, DF: Senado Federal, 2011.

SOUZA, Octavio Tarquínio. Bernardo Pereira de Vasconcelos. Brasília, DF: Senado Federal, 2015.

TELLES, Pedro Carlos da Silva. História da engenharia no Brasil: séculos XVI a XIX. Rio de Janeiro: Livros Técnicos e Científicos, 1983.

THE NEW INTERNATIONAL ENCYCLOPAEDIA. Iron and steel, metallurgy of. [S. $l .:$ s. $n$.], 1905. Disponível em: <https://bit.ly/31SqfZ0>. Acesso em: 21 set. 2021.

TOMASEVICIUS FILHO, Eduardo. Entre a memória coletiva e a história de "cola e tesoura": as intrigas e os malogros nos relatos sobre a Fábrica de Ferro de São João de Ipanema. 2012. Dissertação (Mestrado em História) - Universidade de São Paulo, São Paulo, 2012.

VARNHAGEN, Francisco Adolfo de. História geral do Brasil. Rio de Janeiro: Laemmert, 1857. v. 2.

YONEKURA, Seiichiro. The Japanese iron and steel industry, 1850-1990: continuity and discontinuity. London: Macmillan, 1994.

Artigo apresentado em: 15/11/2020. Aprovado em: 09/04/2021.

\section{(c) BY}

All the contents of this journal, except where otherwise noted, is licensed under a Creative Commons Attribution License 